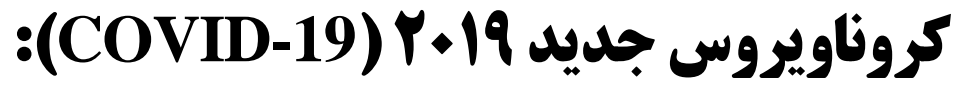 \\ بيمارى عفونى نوظهور در قرن

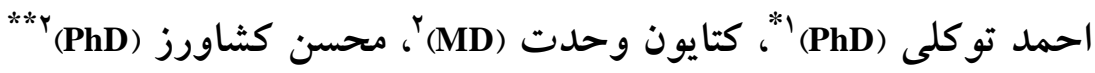 \\ ' كروه ويروس شناسى بزشكى، دانشكده بزشكى، دانشعاه علوم بزشكى ايران، تهران، ايران

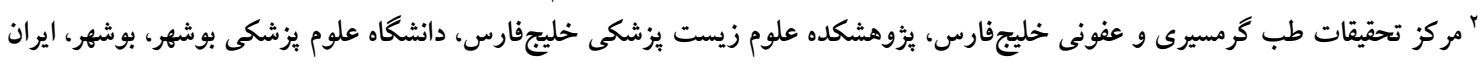

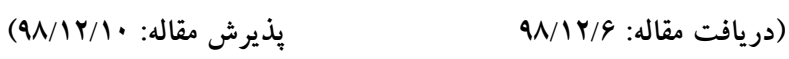

جكيده

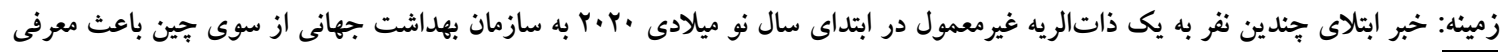

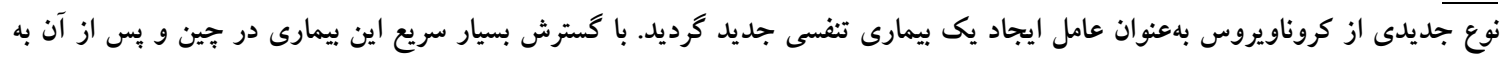

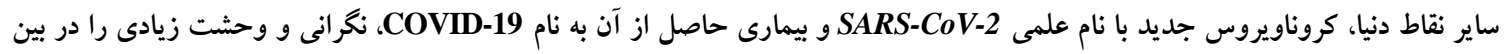

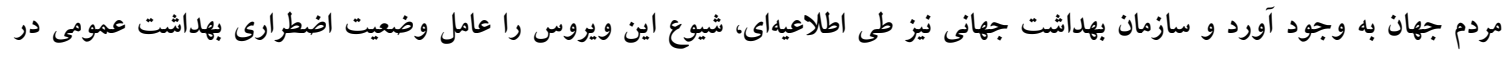
سر تاسر جهان اعلام نمود.

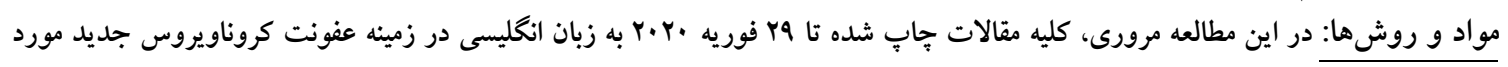

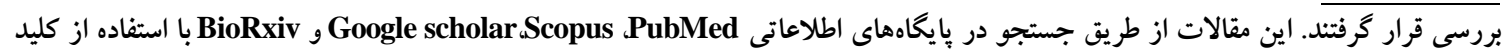

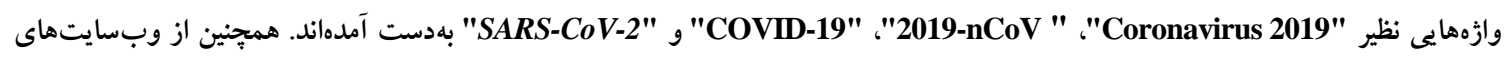

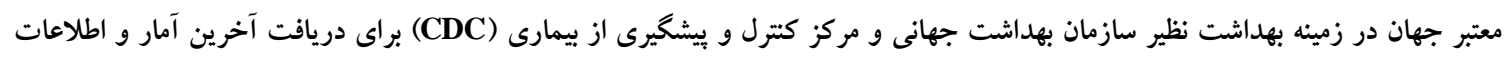

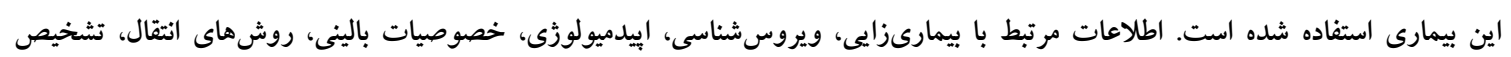

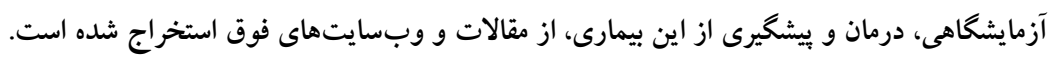

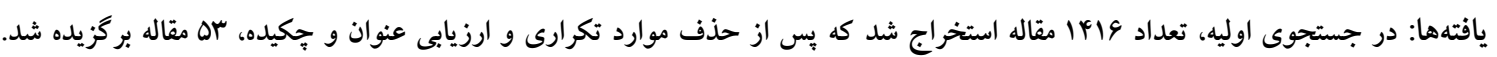

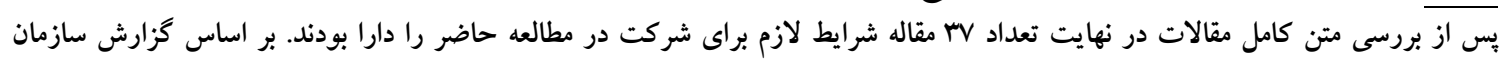

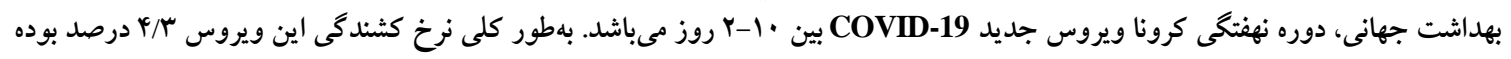

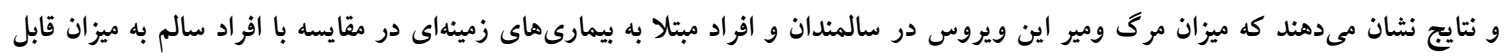

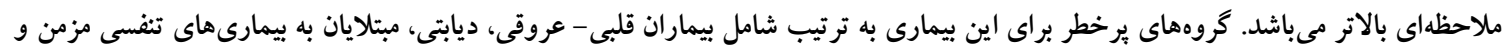

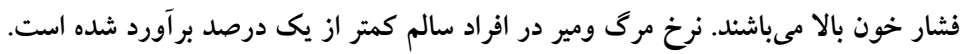

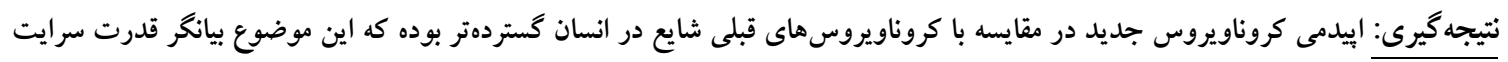

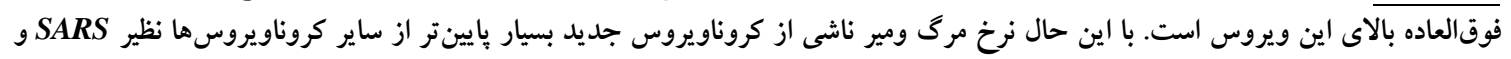

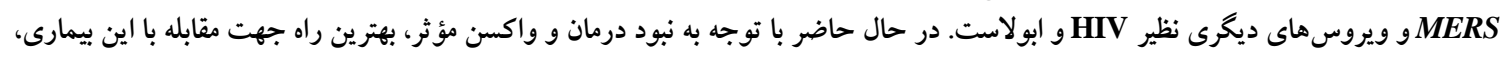

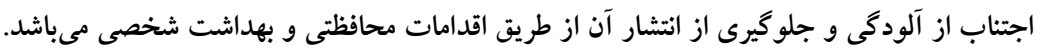

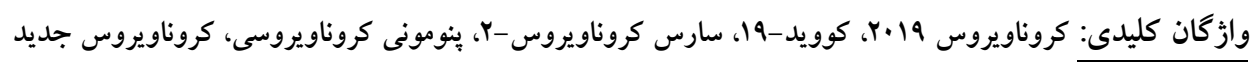

*** مركز تحقيقات طب گرمسيرى و عفونى خليجفارس، يزوهشكده علوم زيست بزشكى خليجفارس، دانشخاه علوم يزشكى بوشهر، بوشهر، ايران

Email: Keshavarz.m@bpums.ac.ir

*ORCID: 0000-0003-1857-0610

**ORCID: 0000-0002-3647-1619 
از ساخت كيتهاى تشخيصى مناسب، موارد مشكوى

ديخرى از اين بيمارى در نواحى ديخر جهان شامل ويتنام،

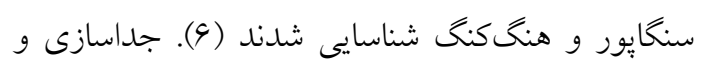

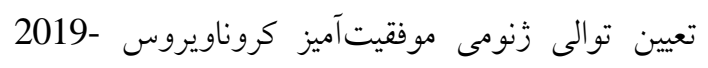
دCoV

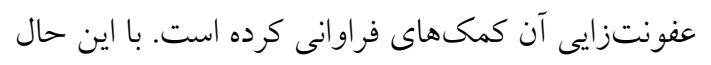

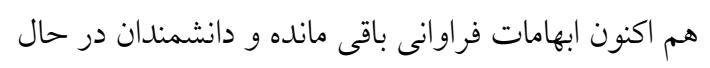

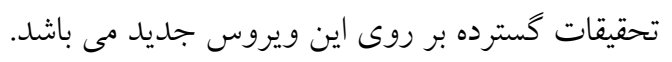

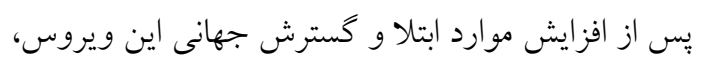

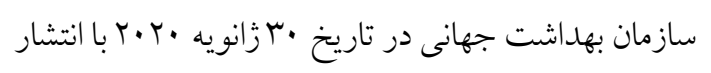
بيانيهاى، شيوع كروناويروس جديد را ششمين عامل وضعيت اضطرارى بهداشت عمومى در سرتاسر جهان اعلام نمود كه تهايدى نه فقط براى جين، بلكه براى تمام

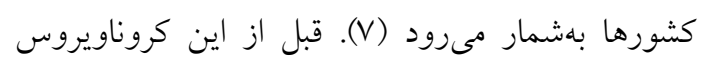

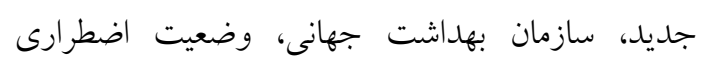

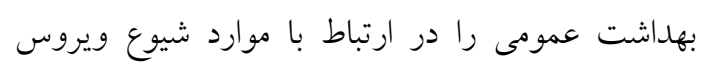

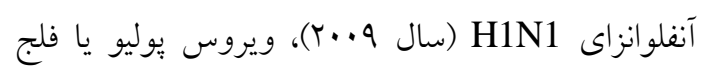

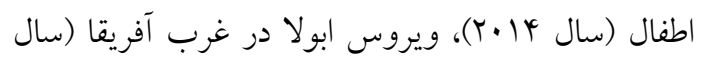

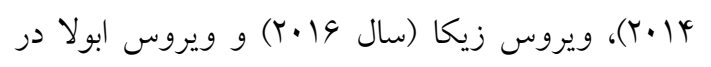

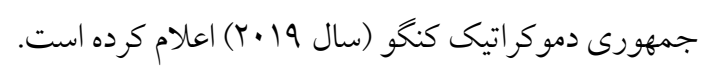
بدينترتيب براى جلو گيرى از انتشار كروناويروس جديديد،

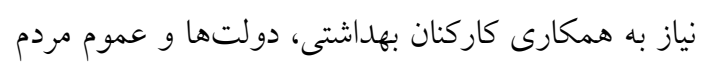

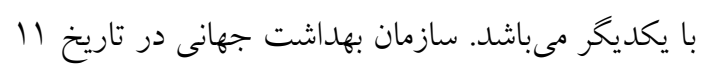

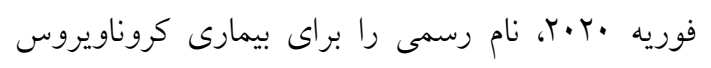

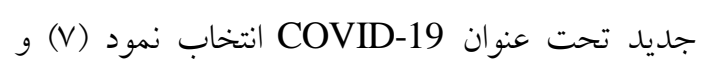
كميته بينالمللى طبقهبندى ويروسها (ICTV) نيز در ندرد همين روز، نام ويروس ايجاد كننده اين بيمارى را از 2019-nCoV به SARS-CoV-2 تغيير داد (A). طبقهبندى طبقهبندى جديد، خانو اده كروناويريده را به دو زير خانواده

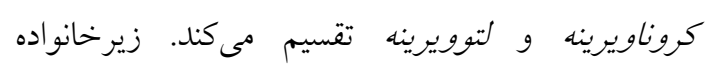

در T9 دسامبر 19 آ، يزشكان بيمارستانى واقع در شهر ووهان جين متوجه موارد غيرمعمولى از بيماران مبتلا به ديه

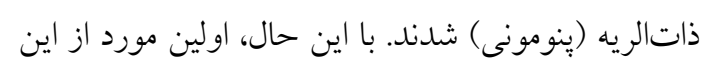

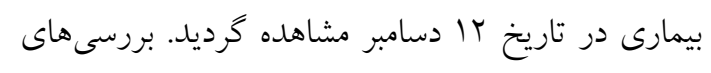
بعدى نشان داد كه منشأ اين بيمارى از بازار غذاهاى درئ

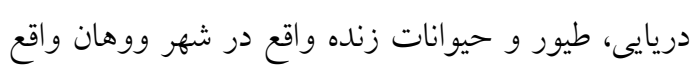

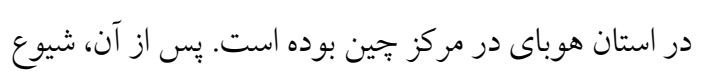
غيرمعمول موارد ذاتالريه در تاريخ اس دسامبر به سازمان بهاشت جهانى كزارش شد. در تاريخ يكم زانويه .T.T.

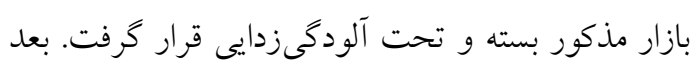

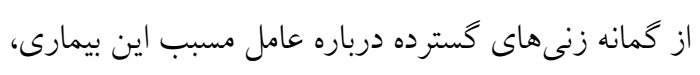
سرانجام بخش جينى مركز كترل و بيشخيرى بيمارى (CDC)

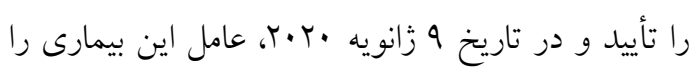
يك كروناويروس جديد با نام 2019-nCoV اعلام نمود اولين توالى زنومى 2019-nCoV يك روز بعد از تأييد آن توسط زانخ (Zhang) و دانشمندان ديخر در دانشگاه فودان شانخهاى به صورت آنلاين قرار كرفت (س). متعاقباً در تاريخ لا زانويه، بنج توالى زنومى ديخر از اين ويروس

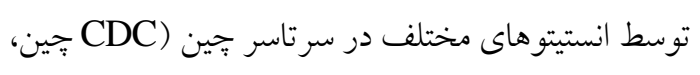

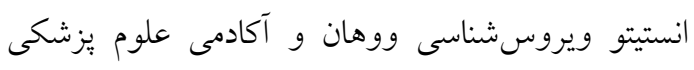

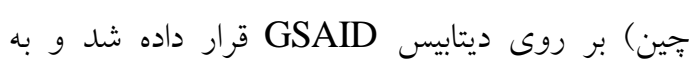

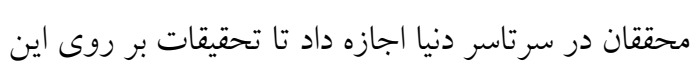
كروناويروس جديد را آغاز كند (4). تا تاريخ Vا زانويه، كو مورد از اين كروناويروس در جين و سه سه مورد ديخر در

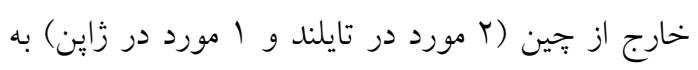

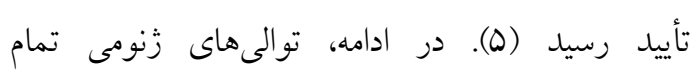

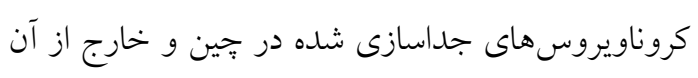

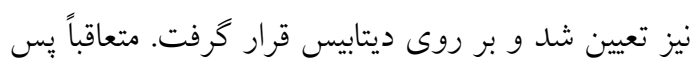




$$
\text { ويروس شناسى }
$$

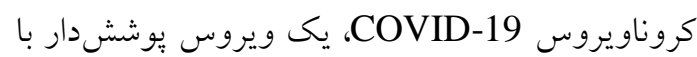

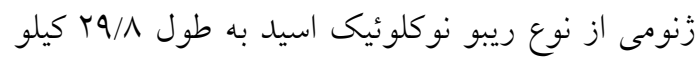

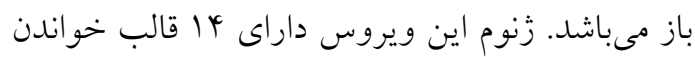

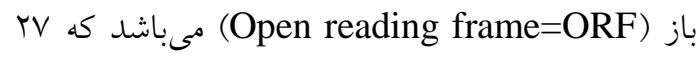
يروتئين را كد مى كنند. زنهاى orflab و orfla كه در

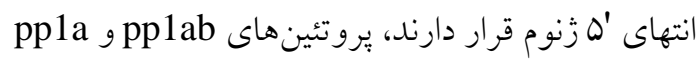
را به ترتيب كد مى كنند. اين دو زن با همديخر 10

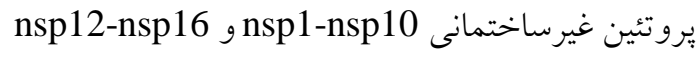

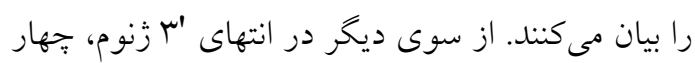

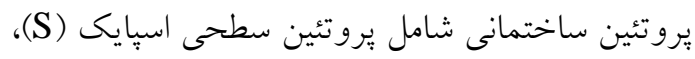

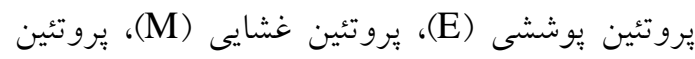

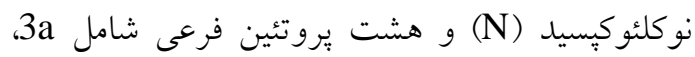

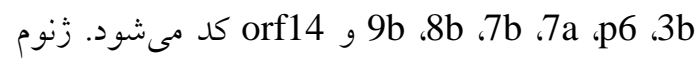
كروناويروس جديد در بعضى نواحى، تفاوتهاى قابل توجهى با زنوم كروناويروس SARS دارد. به عنوان مثال، تيروتئين 8a در كروناويروس SARS وجود داردي؛ در حالى كه اين يروتئين در كروناويروس جديد يدونيد وجود ندارد. همجنين بروتئين 8bSARS-CoV-2

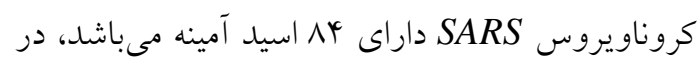
حالى كه طول اين بروتئين در كروناويروس جديد بلندتر و ابا اسيد آمينهاى مى باشد. SARS-CoV-2 از طرف ديخر، يروتئين 3b در كروناويروس

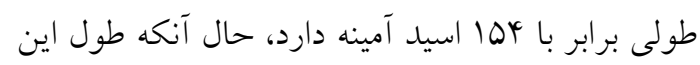

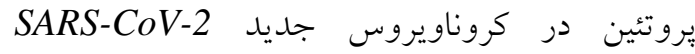

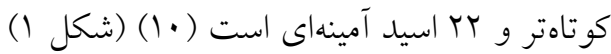

كروناويريده شامل جهار جنس آلفا كروناويروس، بتا كروناويروس، كاما كروناويروسها و ولتا كروناويروسها است. كروناويروسهاى انسانى $229 E$ و جنس آلفا كروناويروس و كرونس كروناويروسهاى انساى انسانى SARS MERS HKU-1 كروناويروس قرار مى گيرند. با مشخص شدن توالى زنومى

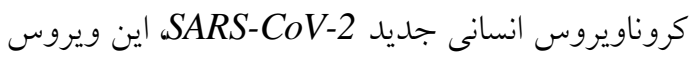
نيز در جنس بتا كروناويروس قرار داده شده است. روى هم رفته تاكنون V Vروناويروس انسانى شناسايى شده است كه دو مورد آن در جنس آلفا كروناويروس و ينج مورد آن در جنس بتا كروناويروس قرار دارند. SARS-CoV-2 سومين كروناويروس يس از دو ويروس SARS و در دو دهه اخير است كه با عبور از گونهاى حيوانى

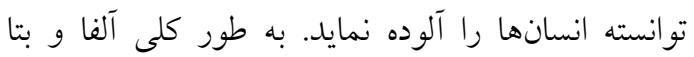

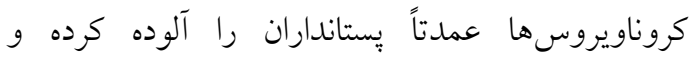
بيمارىهاى انسانى و حيوانى ايجاد مى كنن. در مقابل، كاما

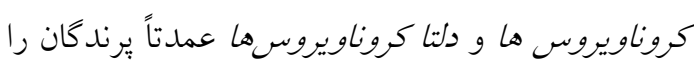

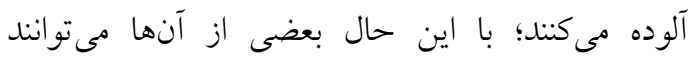

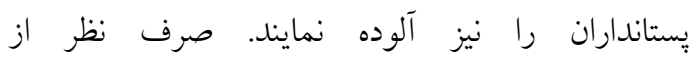
كروناويروسهاى انسانى كه به آن اشاره شده است، آلنا كروناويروس ها شامل كروناويروس هاى خفاشى مختلف، كروناويروس جوندگان نظير موش، كروناويروس راسو و

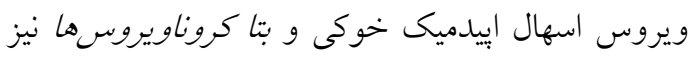

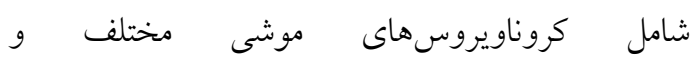
كروناويروس هاى خفاشى متعدد مىباشند (9).

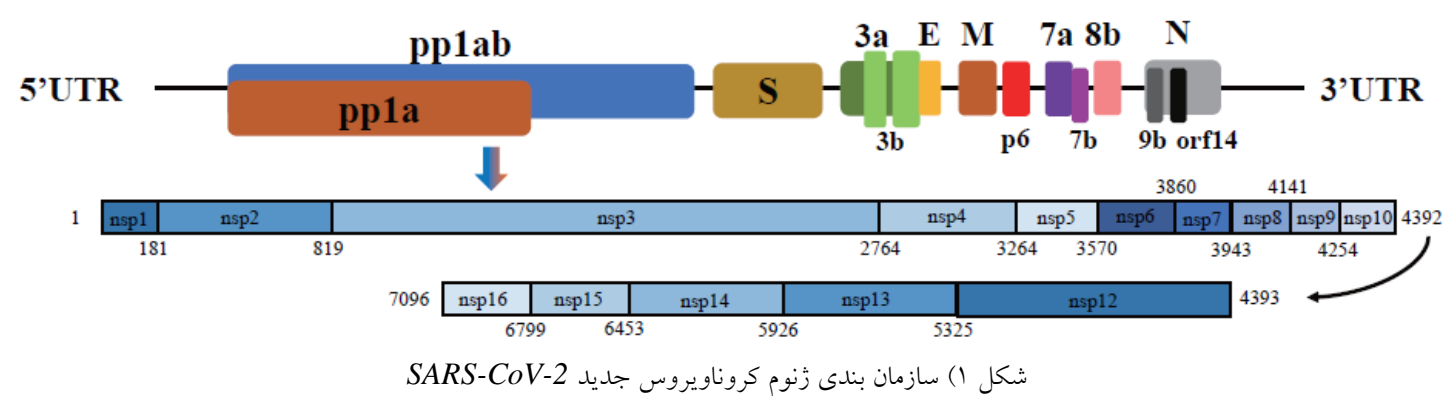

http://bpums.ac.ir 
آلوده به فضولات خفاشها در اين بازار يا نواحى اطراف

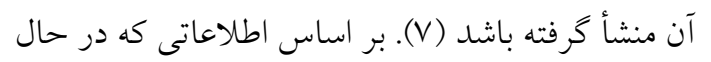
حاضر وجود دارد، به نظر مىرسد كه ميزبان اوليه و طبيعى كروناويروس جديل، خفاشها هستند و در ادامه، اين ويروس وارد يك ميزبان حدواسط (احتمالاً

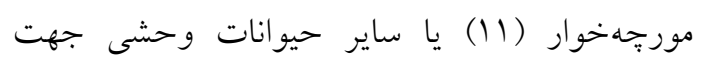

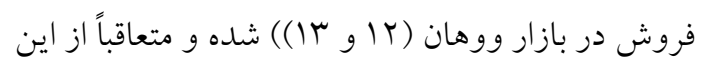
ميزبان حدواسط به انسان منتقل شده است. سبر فر فرآيند

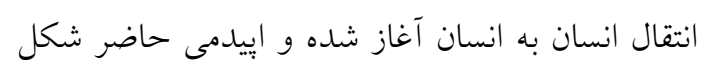

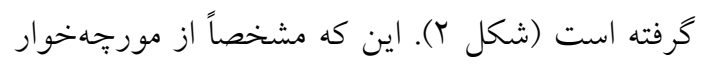

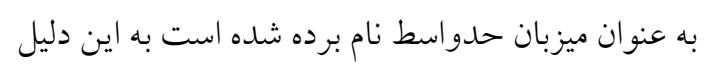

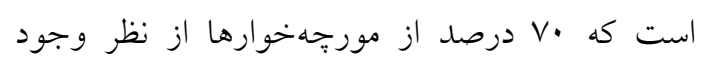

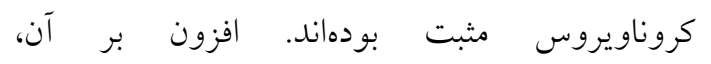

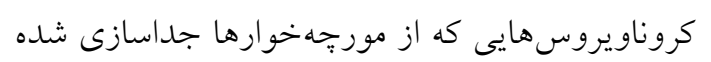

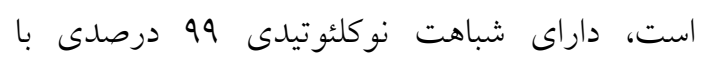

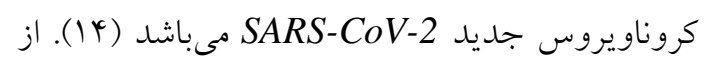
اين رو، اين كه مورجهه خوارها به عنوان ميزبان حدواسط

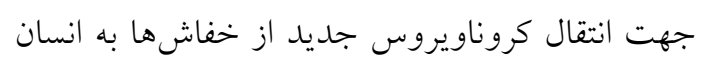
عمل كنند بسيار محتمل به نظر مى رسد.
آناليز فيلوزنتيكى نشان داده است كه كروناويروس جديد SARS-CoV-2 با دو كروناويروس شبه SARS

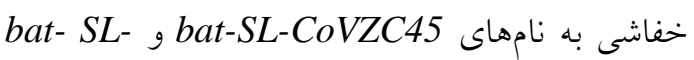
CoVZXC21

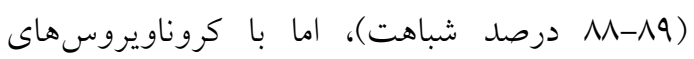
SARS شباهت كمترى دارد. آناليز فيلوزّنتيكى همجنين نشين نشان

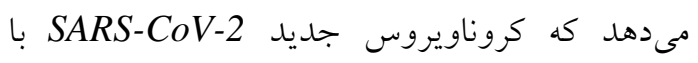
كروناويروس در كردش در رينولوفوس (خفاشهاى

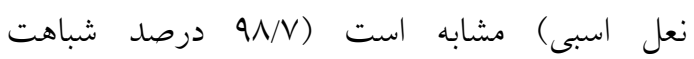

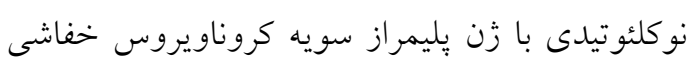

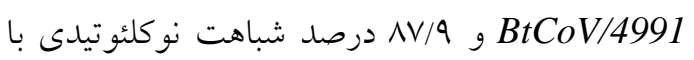
كروناويروس خفاشى سويه bat-SL-CoVZC45 و bat-SL-CoVZXC21 اين كروناويروسهاى خفاشى و كروناويروس جديد SARS-CoV-2 داراى يك جد مشترك مى باشند. بر اساس يافتهاى حاصل از تحقيقات زنومى و وند

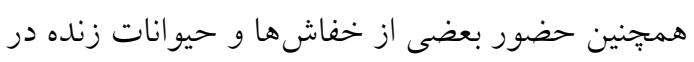
بازار مواد غذايى دريايى در شهر ووهان، كروناويروس بـوسي جديد SARS-CoV-2 ممكن است از خفاشها يا مواد
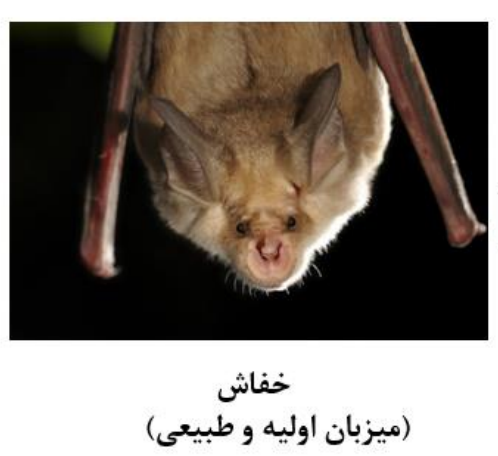

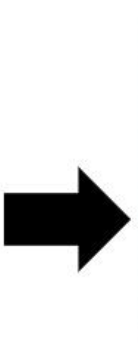

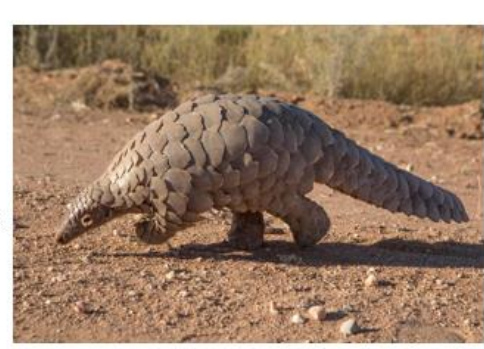

مورجه خوار يا ساير حيوانات وحشى (ميزي

(ميزبان حدواسط)

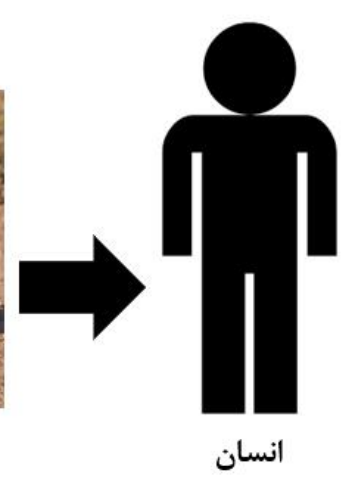

شكل Y) مسير احتمالى انتقال اوليه كروناويروس عامل بيمارى COVID-19

تعيين كننداى در كرايش بافتى ايفا مى كند. مطالعات قبلى نشان داده است كه ويروس SARS براى ورود به داخل
كليكويروتئين سطحى اسِيايك (S) كروناويروسها، نقش

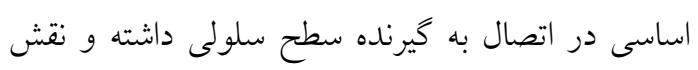


كروناويروس SARS-CoV-2 بهطور كار آمدى در دستگاه تنفسى فوقانى تكثير مى كند. افراد آلوده در طول يكى دوره

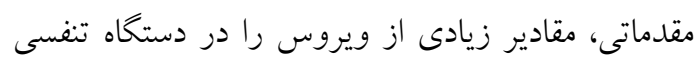
فوقانى خود توليد مى كنند كه اين امر منجر به انتشار بيشتر

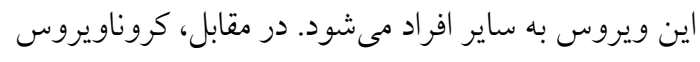
در طول اين دوره مقدماتى به راحتى قابليت انتقال ندارد و بيشترين انتقال زمانى رخ مى دهدل كه فرد بيمار،

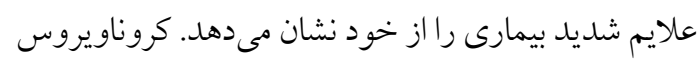
SARS-CoV-2

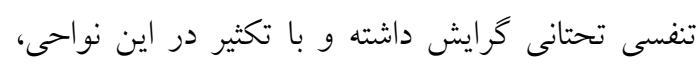

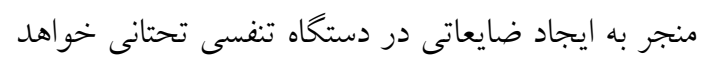

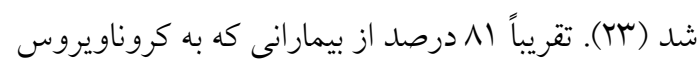
جديد SARS-CoV-2 مبتلا مىشوند، علايم خفيف از

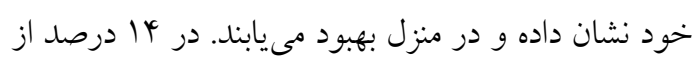

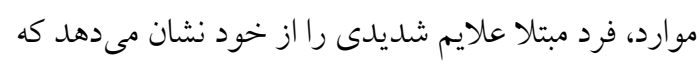

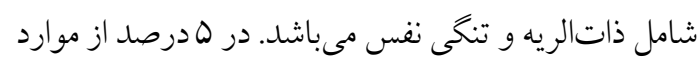

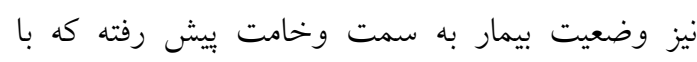

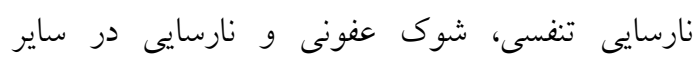
اركانهاى بدن همر اه است (شكل مَ). عفونت با كروناويروس جديد SARS-CoV-2 در مرحله مقدماتى با علايم غيراختصاصى و كلى نظير احساس كسالت، خستخى و بدن درد، تب و سرفه خشكى همراه

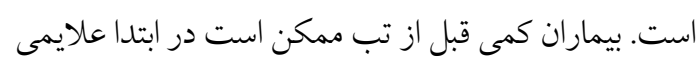
از حالت تهوع و اسهال داشته باشند. تعداد كمى از بيماران ممكن است سردرد يا استفراغ خونى نيز داشته باشند و

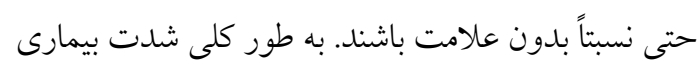

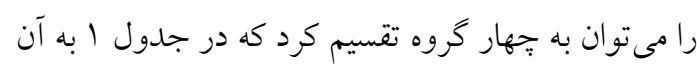

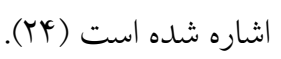

سلول از آنزيم مبدل آنزيوتانسين نوع Y به عنوان كيرنده سلولى استفاده مى كند. در مطالعات اخير نيز مشخص شده ترنه است كه كروناويروس جديد SARS-CoV-2 نيز از آنزيم

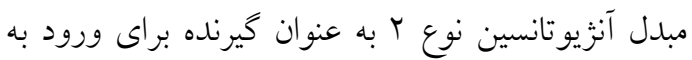

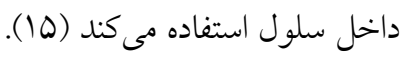

\section{علايم بالينى و ياتوزنز}

بر طبق اولين مطالعه بر روى بيماران مبتلا به

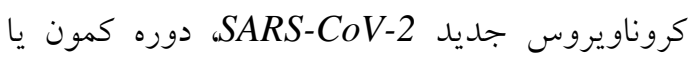
نهفتكى اين ويروس به طور ميانخين ه روز و با دامنه دورئه

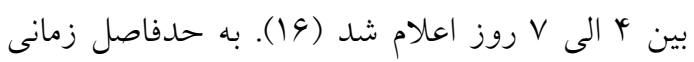
بين مواجهه فرد با ويروس تا ظهور علايم بالينى، دوره

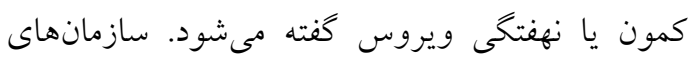
بهداشتى مختلف در دنيا، دوره كمونهاى مختلفى را براى بيمارى COVID-19 بيان كردهاند. بهطورى كه

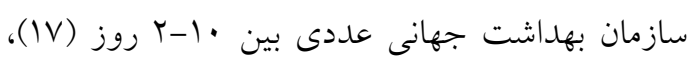

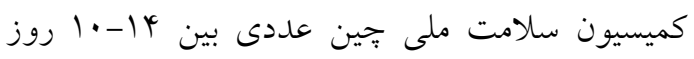

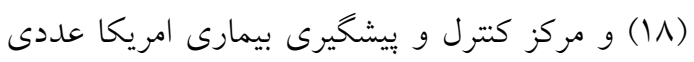
بين Yl| با روز را براى اين دوره مشخص كردهاند (19).

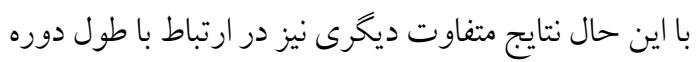
كمون اين بيمارى كزارش شده است. به عنوان مثال، در مطالعهاى كه اخيراً بر روى شش نفر از اعضاى يكى خانو اده آلوده با اين ويروس به انجام رسيده است، مشخص شده

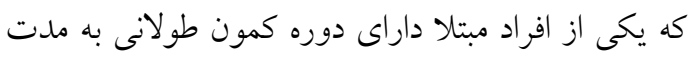

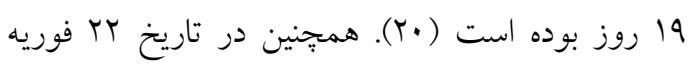

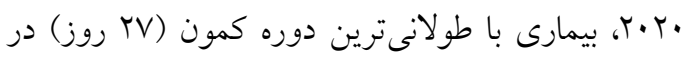

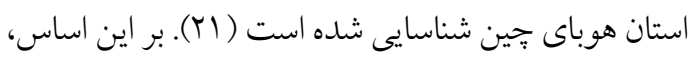
مدت زمان دوره كمون يا نهفتخى بيمارى COVID-19

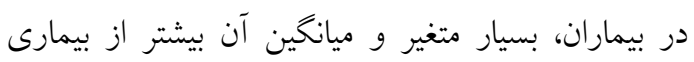
SARS 


\begin{tabular}{|c|c|}
\hline \multicolumn{2}{|l|}{ جدول () معيارهاى شدت بيمارى COVID-19 ناشى از كروناويروس SARS-CoV-2 } \\
\hline مشخصات & 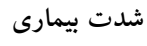 \\
\hline تصويرى از ذات الريه خليف (تب بالاى مبا درجه سانتى گراد، همراه با سرفه يا بدون سرفه، نبود تنكى نفس، نفس نفس نزدن، نبود بيمارى زمينهاى)، نبود يافتههاى & 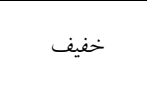 \\
\hline تب، علايم تنفسى، يافتههاى تصويرى از ذاتالريه & 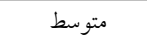 \\
\hline 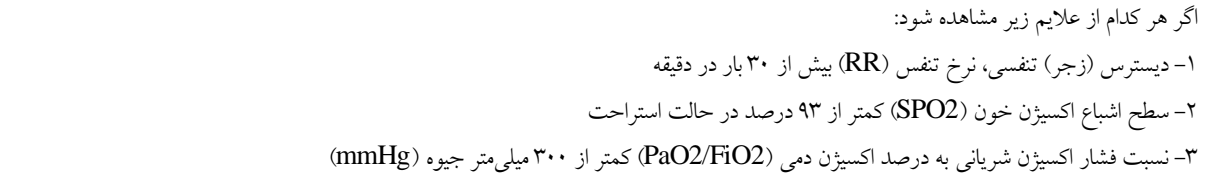 & 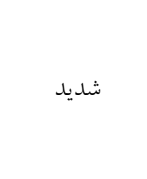 \\
\hline 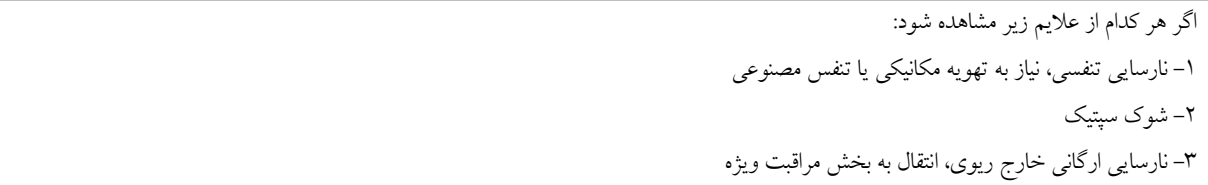 & 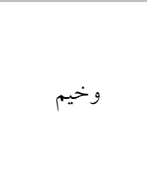 \\
\hline
\end{tabular}

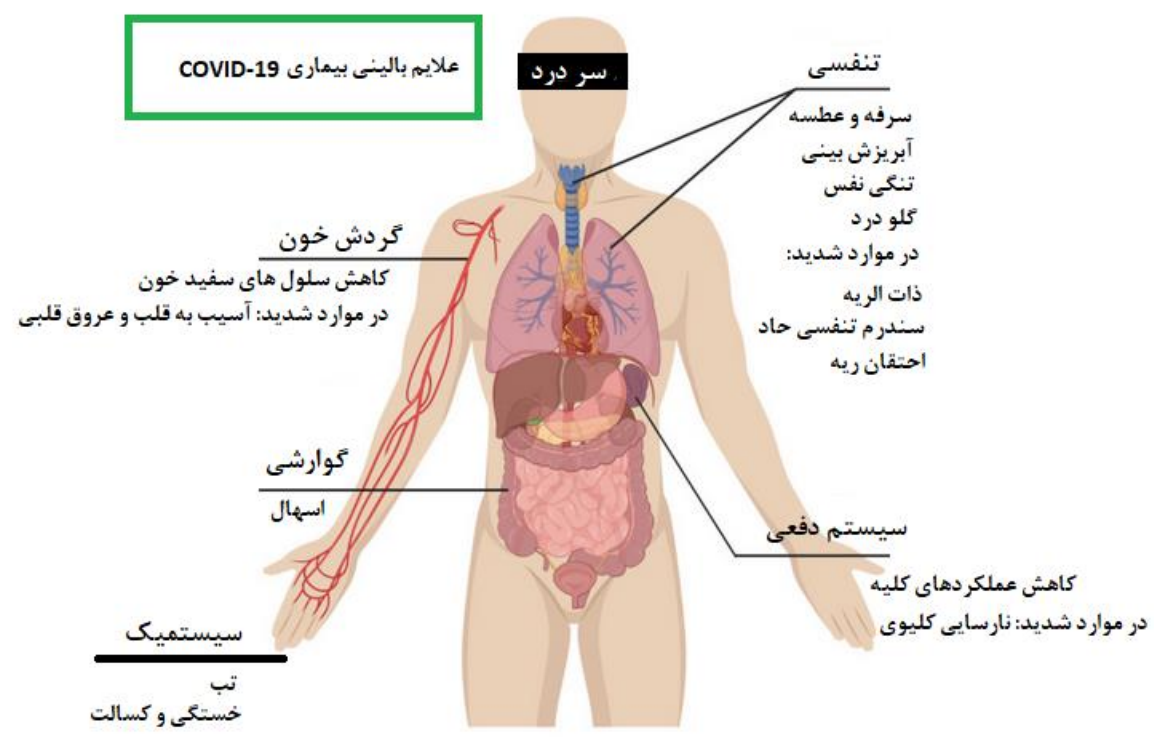

شكل r) تظاهرات بالينى بيمارى COVID-19 در اندامهاى مختلف بدن انسان

عفونت بودند (TO). اين يافتهها در مطالعه ديخرى كه در جين انجام شد نيز مورد تأييد قرار كرفت (Y) (Y).

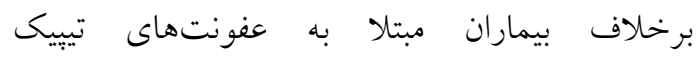
كروناويروسى، علايم دستخاه تنفسى فوقانى نظير كلو

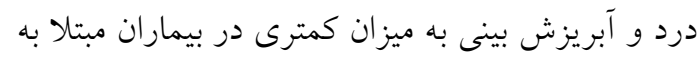

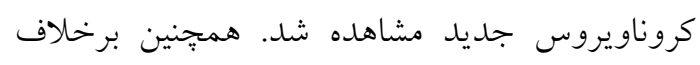

مطالعهاى كه توسط هو آنخ (Huang) و همكاران روى

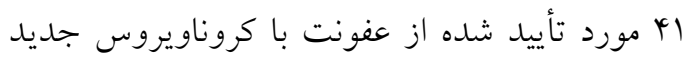
بسترى در بيمارستان ووهان به انجام رسيد مشخص نمود كه تب (91 درصد)، سرفه (V9) درصد)، تنكى نفس ( (ه درصد) و درد عضله و خستخى

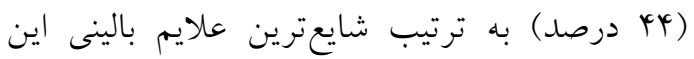


را مشخص نمايد. نتايج بررسى SARS-CoV-2 نشان داده است كه مردان بيشتر از زنان به عفونت

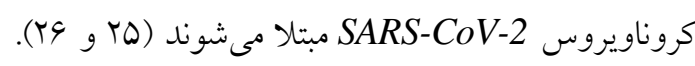
زنهاى مرتبط با ايمنى بر روى كروموزوم ايكس و و

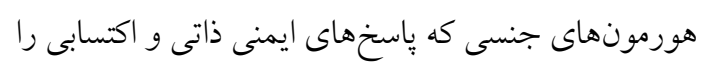
تحت تأثير قرار مى دهند، ممكن است توجيه كننده استعداد بيشتر مردان به اين عفونت باشند (و و • •r). احتمال بالاتر

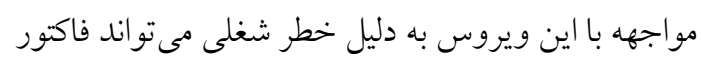
مشاركت كننده ديخرى براى اين موضوع باشد.

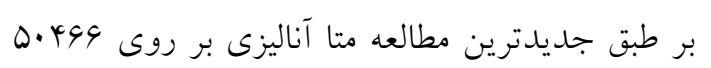

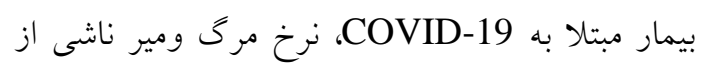

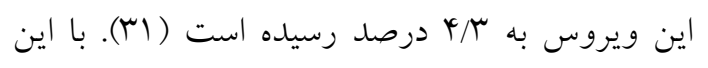

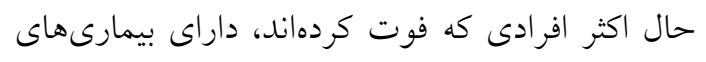

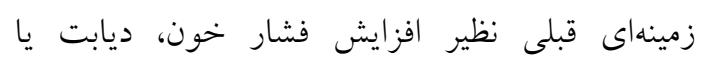
بيمارىهاى قلبى - عروقى بودهاند كه سيستم ايمنى آنها تضعيف شده است (جدول Y). نتايج اين مطالعه كسترده

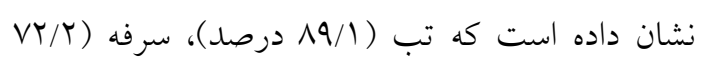

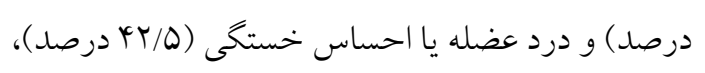
شايعترين علايم بالينى بيماران بوده است. همجنين

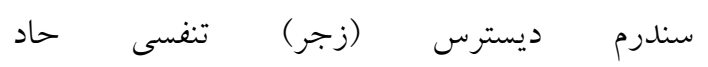
در (Acute Respiratory Distress Syndrome) 1 ا درصد و راديوكرافى غيرطبيعى قفسه سينه در 94/9 درصد از موارد مبتلا به

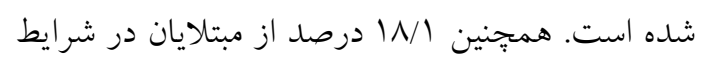

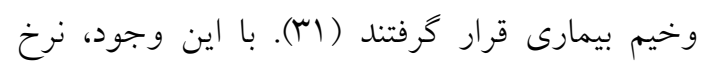

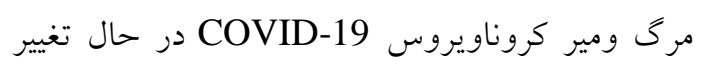
بوده و تعداد موارد بهبود يافته در حال افزايش مى باشد.

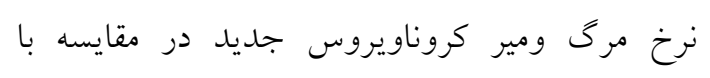

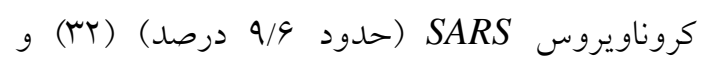
كروناويروس MERS (حدود ميزان قابل توجهى كمتر است.
كروناويروس SARS علايم كوارشى نظير اسهال به

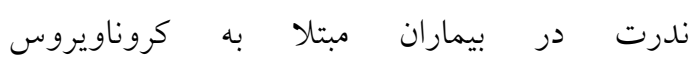
SARS-CoV-2 شباهت هاى بين كروناويروس SARS-CoV- و 2، گمانه زنىها در مورد ويرمى (حضور ويروس دروسئ دروس

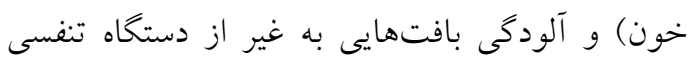

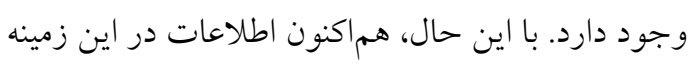
وجود ندارد. همانند عفونت با كروناويروس SARS نتايج حاصل از اشعه ايكس قفسه سينه و توموگرافى، درگيرى دو طرفه

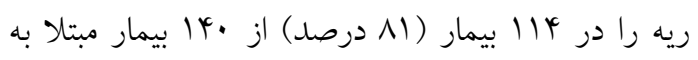
عفونت كروناويروس SARS-CoV-2 نشان داده است رون

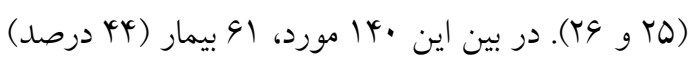

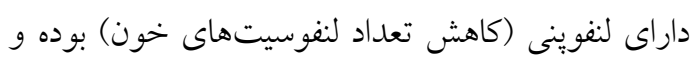

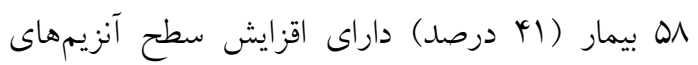
آسيارتات آمينو ترانسفراز (AST) يا آلانين آمينو ترانسفراز بالاتر از محدوده مجاز بودند (QLT) بيوماركرهاى مرتبط با عفونت، سطوح برو كلسى تونين در

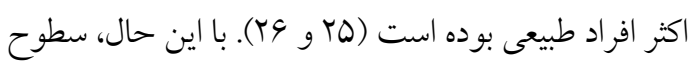
فريتين سرمى و بروتئين واكنشى C انسانى (CRP)

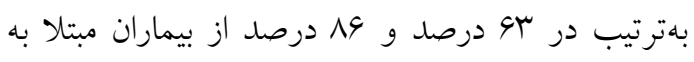
كروناويروس جديد افزايش يافته است (צr). همانند يافتهاى بهدست آمده در مورد عفونت كروناويروس يكائس سطوح سايتوكاينهاى بيش التهابى بِاسمايى در

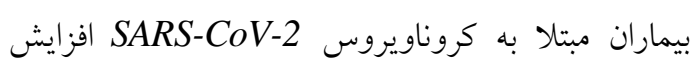

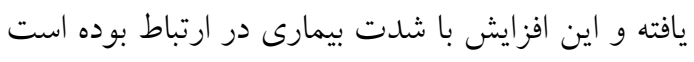

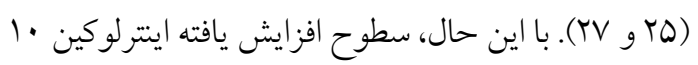

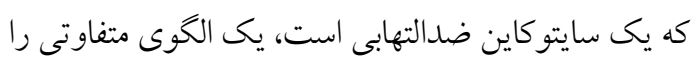
در مقايسه با عفونت كروناويروس SARS نشان مىدهد

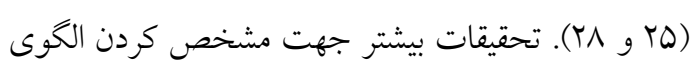
سايتوكاينى اين بيماران مىتواند بِاتوزنز كروناويروس 


\begin{tabular}{|c|c|}
\hline \multicolumn{2}{|c|}{ 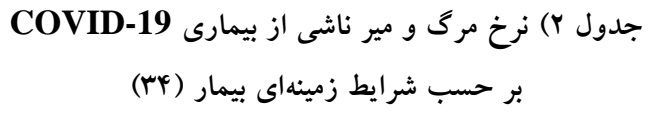 } \\
\hline نرخ مرگ ومير (درصد) & شرايط زمينهاى \\
\hline $1 \cdot / 0$ & بيمارى قلبى - عروقى \\
\hline$v / r$ & ديابت \\
\hline $9 / \pi$ & بيمارى مزمن تنفسى \\
\hline 4 & فشار خون \\
\hline$\Delta / 9$ & سرطان \\
\hline$\cdot / 9$ & بدون بيمارى زمينهاى \\
\hline
\end{tabular}

CoV-2 قلبى- عروقى يا مغزى- عروقى هستند. محققان همجنين اختلاف بزرگى را در ميزان مرگ ومير بر برى

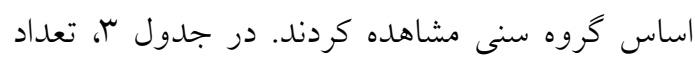

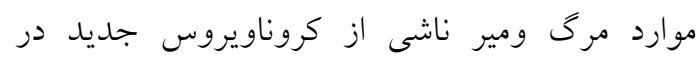
كروههاى سنى مختلف در بين MYGY مشخص شده است.
بررسىهاى اوليه نشان داده است كه افراد مبتلا به بيمارىهاى زمينهاى در معرض خطر بيشترى براى إى ايجاد عوارض و مرى ومير ناشى از بيمارى COVID-19

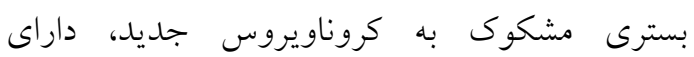

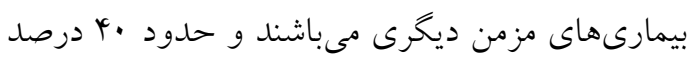
از بيماران بسترى كه عفونت كرناويروس جديد - SARS

\begin{tabular}{|c|c|c|c|}
\hline \multicolumn{4}{|c|}{ 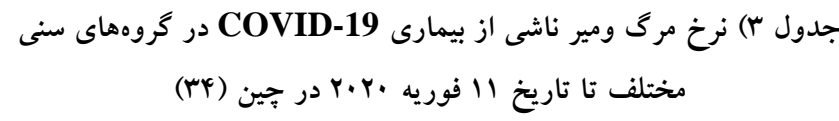 } \\
\hline $\begin{array}{c}\text { نرخ مرگ ومير } \\
\text { (درصد) }\end{array}$ & تعداد موارد & تعداد موارد تأئيد شده & گرووه سنى \\
\hline . & . & 419 & .9-9 سال \\
\hline$\cdot \pi$ & 1 & QYq & •19-19 سال \\
\hline$\cdot \pi$ & v & rela & •rq-r ساJ \\
\hline$\cdot \pi$ & 11 & va.. & r ra-ra سال \\
\hline$\cdot / 4$ & rı & $\Lambda \Delta V I$ & 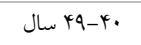 \\
\hline $1 / r$ & ir. & $1 \cdots 1$ & •ه-ه سال \\
\hline$r / 4$ & $r .9$ & $\Lambda \Delta \wedge r$ & 99-99 سال \\
\hline$\wedge$ & MIr & ral1 & سال Vq-V. \\
\hline $14 / 1$ & $r \cdot \Lambda$ & $14 \cdot 1$ & •^م سال به بالا. \\
\hline
\end{tabular}

مشخصه برجسته تصاوير راديولوزيكى در بيمارانى كه به ينومونى شديد كروناويروسى مبتلا شدهاند تشخيص بيمارى COVID-19 متكى به يافته هاى شامل نماى شيشه مات (ground glass opacity)

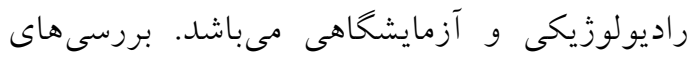
و تراكم ريه (consolidation) است كه مىتواند هر

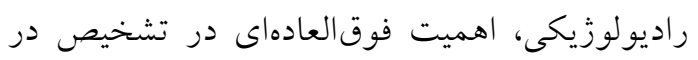
دو ريه را درگير مىنمايد (شكل ؟ب).

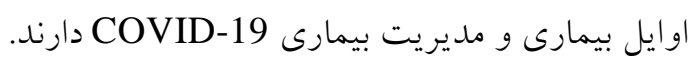




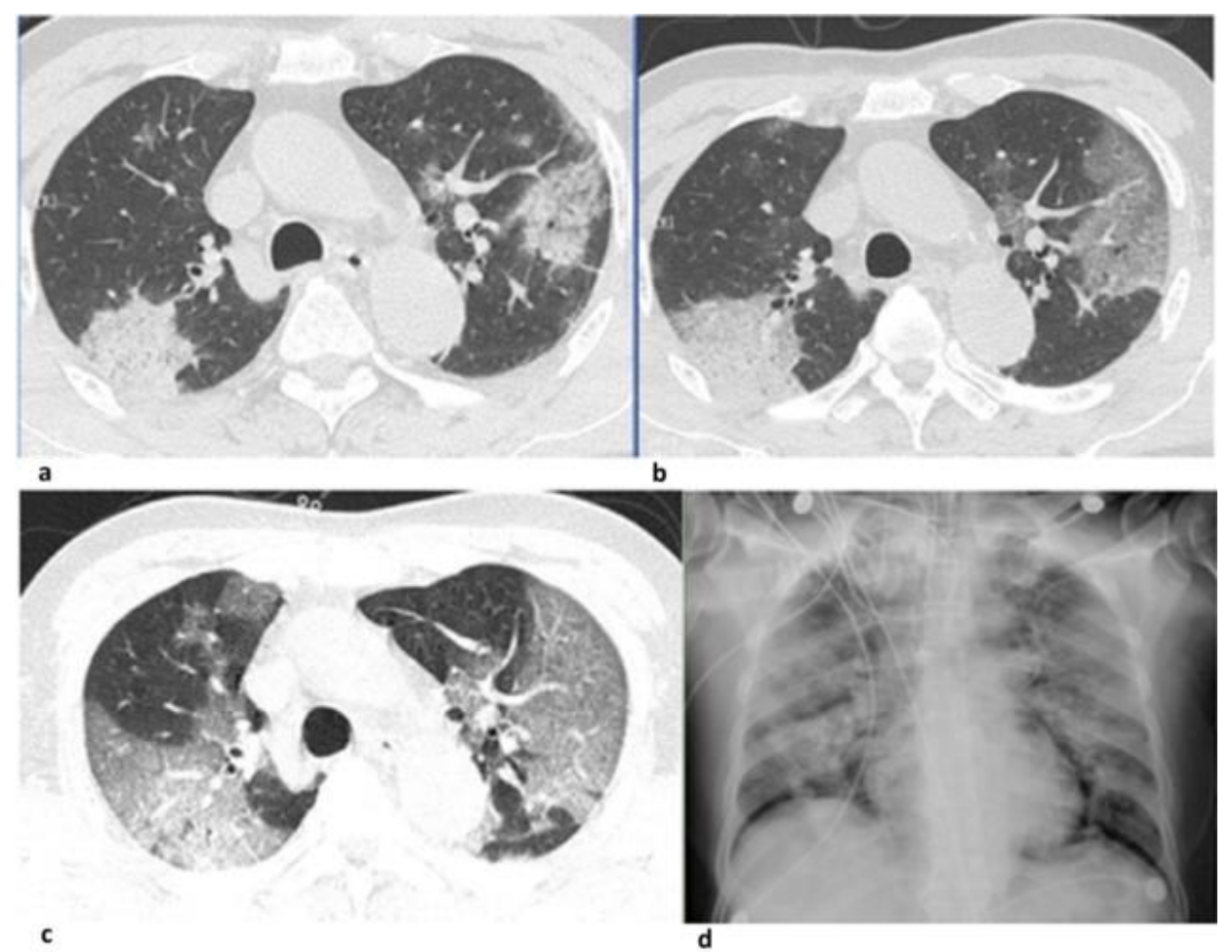

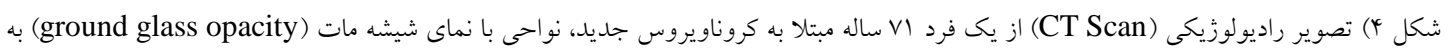

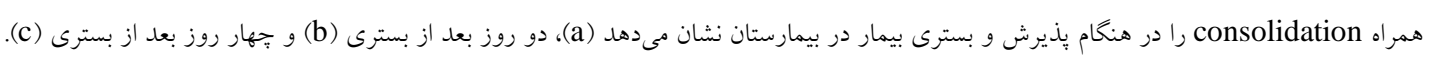

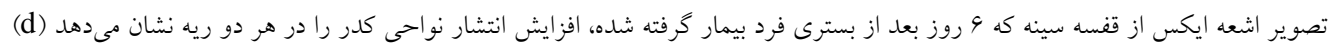

\section{إيدميولوزى و انتقال}

در دسامبر سال 19 • با، اولين علايم بالينى از بيمارانى كه به كروناويروس جديد SARS-CoV-2 مبتلا شده بودند

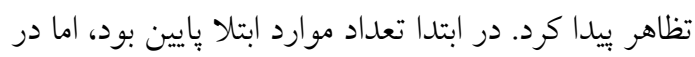

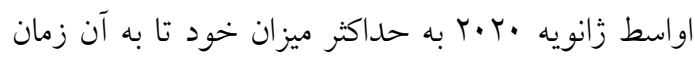
رسيد. در طول نيمه دوم اين ماه و به دليل مسافرت و

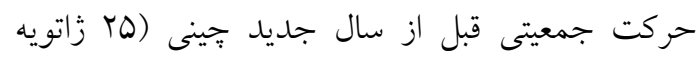
. T.Y.T.

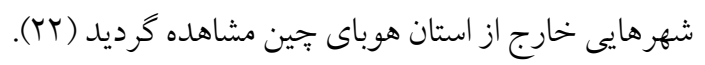

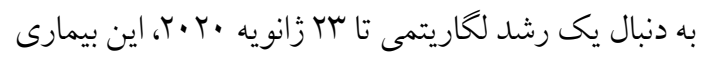

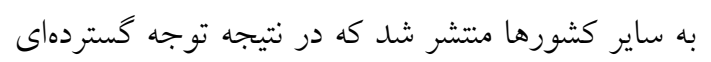
رادر سرتاسر جهان به خود جلب كرد.

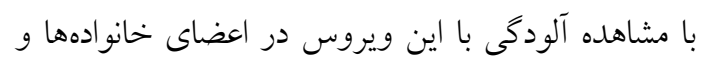

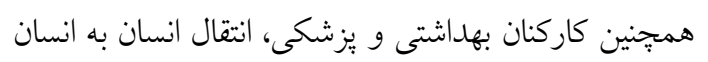

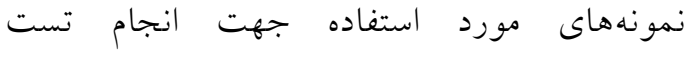
آزمايشخاهى شامل نمونه هاى سواب نازوفارنزيال،

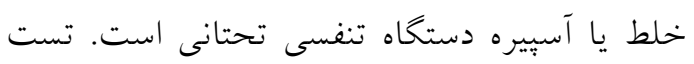

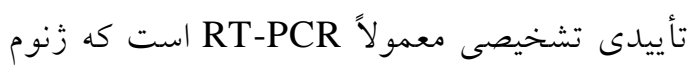
ريبونو كلوئيك اسيد ويروس را مورد شناسايى قرار

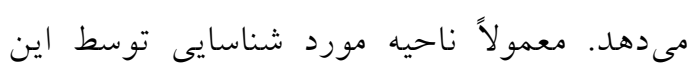

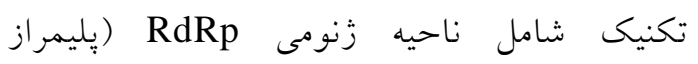

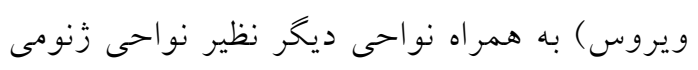

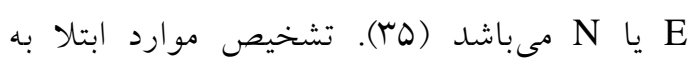
بيمارى COVID-19 از طريق مثبت شدن نتيجه

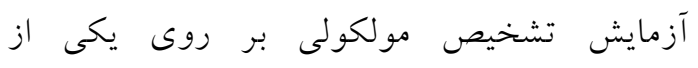

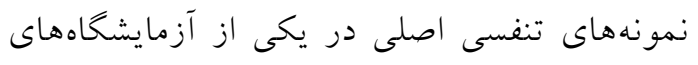

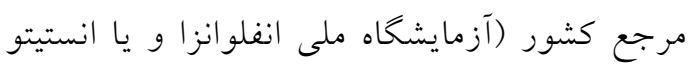
ياستور ايران) است. 
طريق مدفوعى - دهانى قابل انتقال هست يا خير مشخص نيست و موضوع در حال بررسى مىباشد.

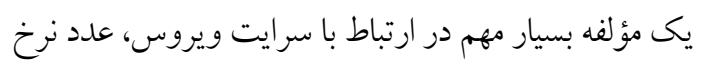

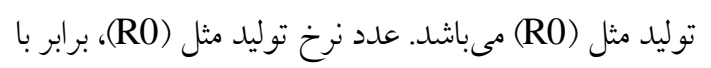

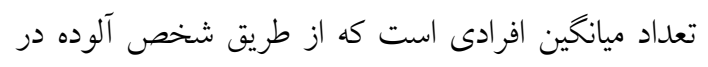
معرض خطر ابتلا به بيمارى قرار دارند؛ با اين فرض كه إنه

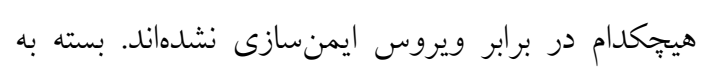
مقدار R0 سه احتمال براى شيوع يا كاهش بيمارى وجود إند

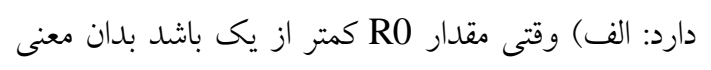
است كه عفونت كمتر از يكى عفونت مولد را ايجاد مى كند.

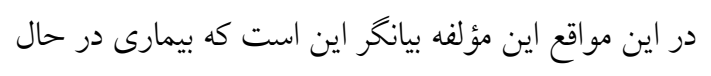
كاهش است. ب) وقتى R0 مساوى با يك باشد، بدان معنى

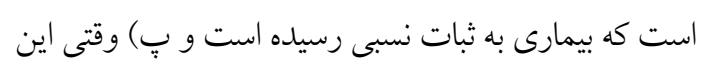

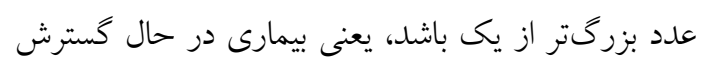

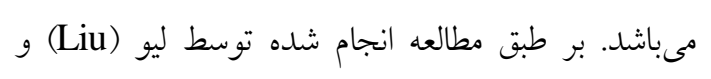

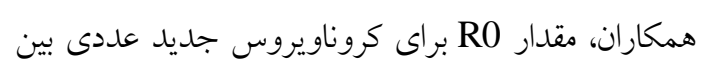

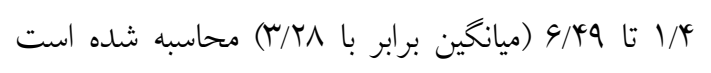

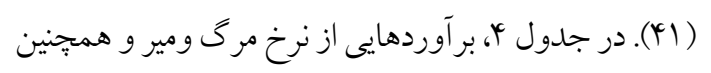
مقدار R0 جندين ويروس نوظهور مشهور بر اساس دادهاى جمع آورى شده از سازمان بهداشت جهانى و مركز كتترل و ييشخيرى از بيمارى ها ارائه شده است (Y) (Y).
اين كروناويروس از طريق قطرات تنفسى و اشياى آلوده به

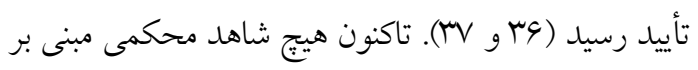

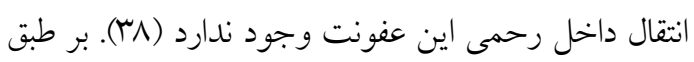

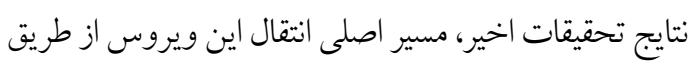
استنشاق قطرات تنفسى آلوده، تماس نزديك (كمتر از و قدم

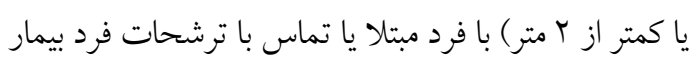

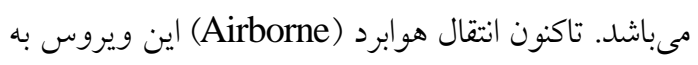
اثبات نرسيده است. قطرات تنفسى آلوده از طريق عطسه يا

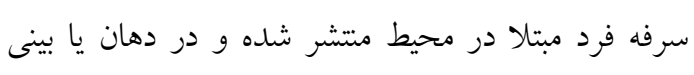

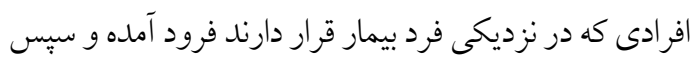

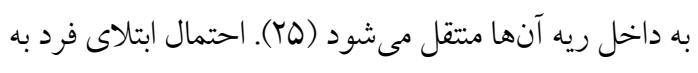
كروناويروس COVID-19 از طريق لمس شى يا سطحى

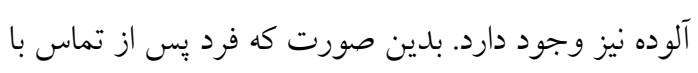

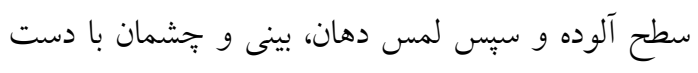
آلوده، ويروس را وارد بدن خود مى كند. بيشترين مقدار

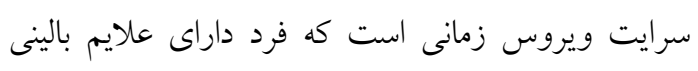
باشد. با اين حال برخى از بيماران قبل از ظهور علايم بالينى

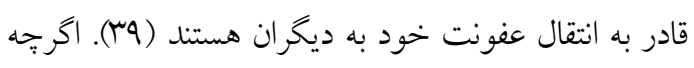
در مواردى، حضور ويروس در مدفوع بيمار نيز شناسايى

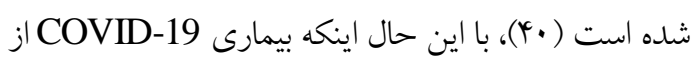

\begin{tabular}{|c|c|c|}
\hline R0 مقدار R0 & نرخ مرگ ومير (درصد) & ويروس \\
\hline $9 / 49$ ا $1 / 4$ & $4 / r$ & SARS-CoV-2 \\
\hline 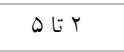 & $9 / 9$ & SARS \\
\hline كمتر از يك & $r \Delta / r$ & MERS \\
\hline كمتر از يك & $4 \cdot$ & انفلوانزاى يرند كان (rا •r) H7N9 \\
\hline 1/9 آ ا &.$/ 4$ & انفلوانزاى (Y. HIN1) \\
\hline r/A 1/4 & r & انفلوانزاى (19|N) HINI \\
\hline ا & $\cdot / r$ & 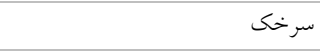 \\
\hline 4 & كمتر از 1•• & راينو ويروس \\
\hline$r / r$ & v. & ابولا \\
\hline$r / 4$ & $\wedge \cdot$ & HIV \\
\hline 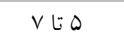 & iv & آبله \\
\hline
\end{tabular}


Vو مورد و در ساير كشورها ( V1991 نفر افزايش يافته است. همجنين تعداد موارد فوتى ناشى

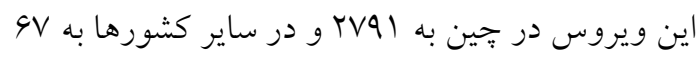
نفر افزايش يافته است. بيشترين موارد تأييد شده اين

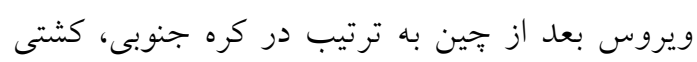

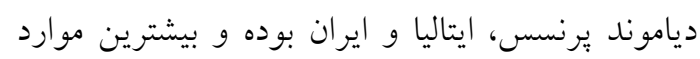

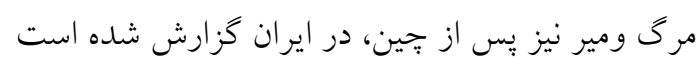

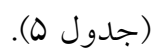

در اواخر زانويه •r.r.r، ابتلاى بيش از • ا هزار نفر با كروناويروس SARS-CoV-2 در سرتاسر جين به تأييد سازمان بهداشت جهانى رسيد. اين تعداد تا تاريخ 19

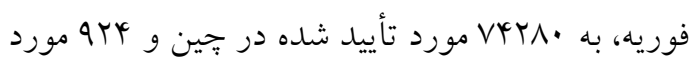

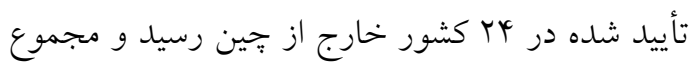

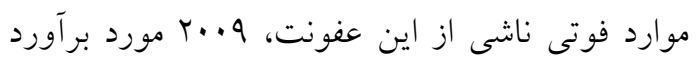
شد (س (Y). بر طبق آخرين گزارشى كه توسط سازمان

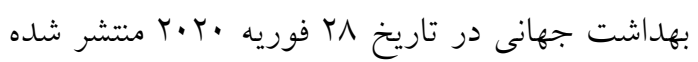

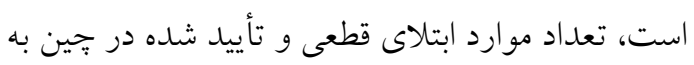

\begin{tabular}{|c|c|c|}
\hline \multicolumn{3}{|c|}{ 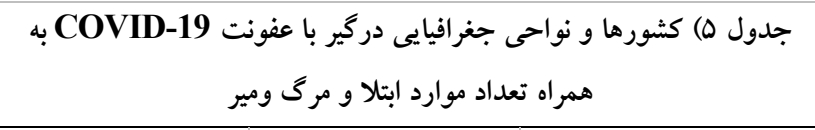 } \\
\hline تعداد موارد فوت شده & تعداد موارد تأييد شده & ناحيه جغرافيايى \\
\hline rval & V^৭४। & جين \\
\hline ir & rmT & كره جنوبى \\
\hline$r$ & $v \cdot \Delta$ & كشتى تفريحى دياموند يُرنسس \\
\hline iv & 90. & يتاليا \\
\hline rq & rYO & 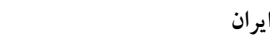 \\
\hline 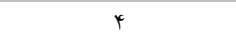 & r. & زإين \\
\hline · & 99 & سنكايور \\
\hline · & $\Delta 9$ & يالات متحده امريكا \\
\hline . & $\mu$ & كويت \\
\hline · & r. & تايلند \\
\hline r & $\mu_{\Lambda}$ & 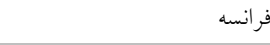 \\
\hline . & m & بحرين \\
\hline . & rq & آلمان \\
\hline$\cdot$ & ro & سيانيا \\
\hline · & re & 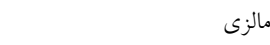 \\
\hline · & rr & استراليا \\
\hline$\cdot$ & 19 & مارات متحده عربى \\
\hline · & 19 & 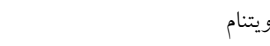 \\
\hline · & 19 & بريتانيا \\
\hline$\cdot$ & 11 & كانادا \\
\hline · & v & 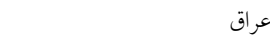 \\
\hline · & $v$ & 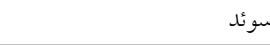 \\
\hline$\cdot$ & 4 & 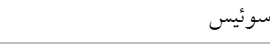 \\
\hline$\cdot$ & 9 & عمان \\
\hline$\cdot$ & $r$ & 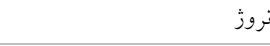 \\
\hline$\cdot$ & $r$ & ت ت ت ت ايش \\
\hline$\cdot$ & r & 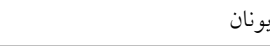 \\
\hline
\end{tabular}




\begin{tabular}{|c|c|c|}
\hline تعداد موارد فوت شده & تعداد موارد تأييد شده & ناحيه جغرافيايى \\
\hline 1 & $r$ & فيلييين \\
\hline . & $r$ & هند \\
\hline . & $r$ & كرواسى \\
\hline . & $r$ & اسرائيل \\
\hline . & r & روسيه \\
\hline . & r & فنلاند \\
\hline · & $r$ & ل لبنان \\
\hline . & r & لِّاكستان \\
\hline · & 1 & كامبوج \\
\hline . & 1 & نيوزلند \\
\hline · & 1 & نيال \\
\hline · & 1 & هلند \\
\hline · & 1 & سريلانكا \\
\hline · & 1 & بلاروس \\
\hline · & 1 & ليتوانى \\
\hline . & 1 & بلزيك \\
\hline$\cdot$ & 1 & افغانستان \\
\hline . & 1 & مصر \\
\hline · & 1 & برزيل \\
\hline · & 1 & دانمارك \\
\hline · & 1 & استونى \\
\hline . & 1 & كرجستان \\
\hline$\cdot$ & 1 & مقدونيه شمالى \\
\hline$\cdot$ & 1 & رومانى \\
\hline · & 1 & نيجريه \\
\hline . & 1 & الجزاير \\
\hline 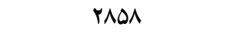 & ArgOr & مجموع \\
\hline
\end{tabular}

داروهاى لوييناوير و ريتوناوير باعث بهبود قابل توجهى در درمان وضعيت بيماران مبتلا به SARS مىشود. همجنين نتايج به دليل آسيبهاى شديد ريوى ناشى از عفونت

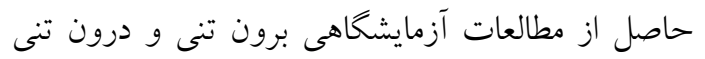
كروناويروس SARS و MERS ميزان مرگ ومير در نشان مىدهد كه تركيبى از داروهاى لوييناوير، ريتوناوير و

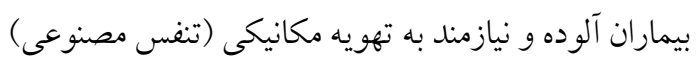
ايتترفرون بتا ممكن است در برابر كروناويروس MERS

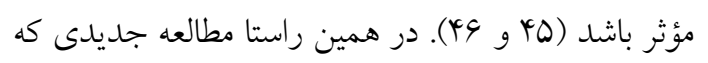

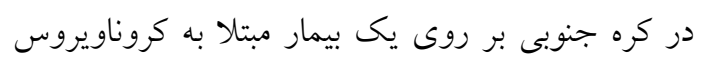

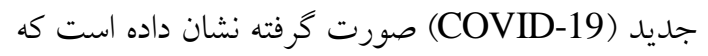

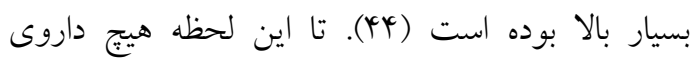

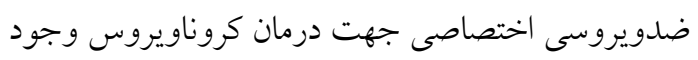
ندارد و راهكار اصلى، مراقبتهاى حمايتى مانند حفظ تهرئ

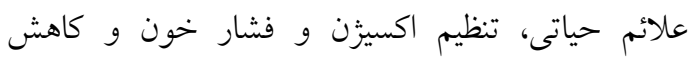
مصرف داروهاى لوييناوير و ريتوناوير موجب كاهش قابل توجه تيتر ويروس و بهبود شرايط بيمار شده است (YV). عوارض ايجاد شده مانند عفونتهاى ثانويه يا نارسايى

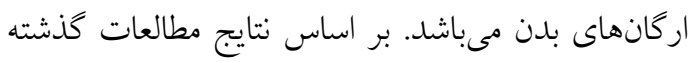

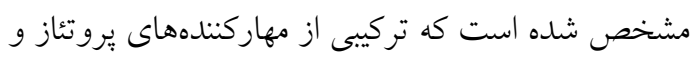


بالينى انجام شده در جين از خود نشان داده است. اين

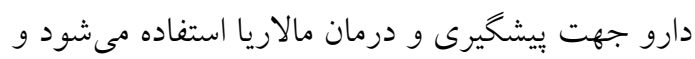
بهنوان يك عامل ضدالتهاب براى درمان آرتريت

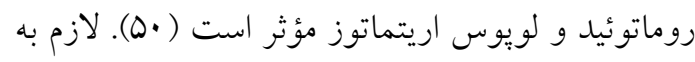

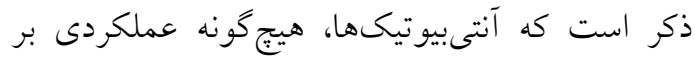
روى ويروسها ندارند و مصرف خودسرانه اين داروها مى تواند عوارض و وييامدهاى جدى برى براى افراد داشته

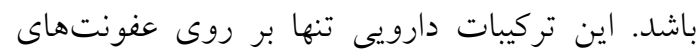

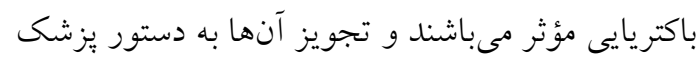

$$
\text { صورت مى گيرد. }
$$

با توجه به نبود درمان استاندارد و واكسن مؤثر براى

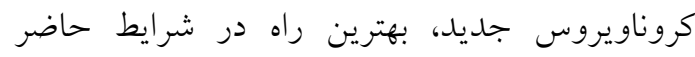

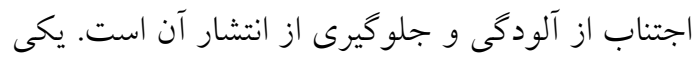

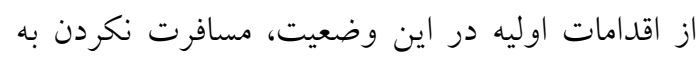
مناطق إيدميك، نخوردن و تماس نداشتن با حيوانات

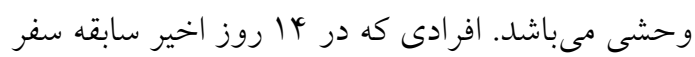

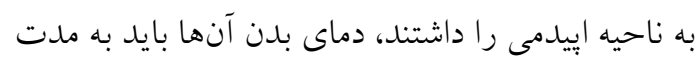

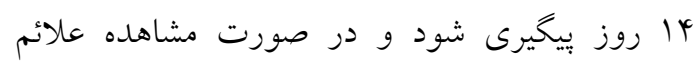

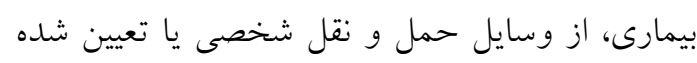
براى قرار نخرفتن در معرض عموم استفاده كنند. همجنين كاركنان بخش بهداشت در هنگحام انتقال بيماران

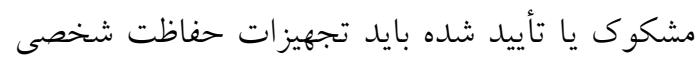

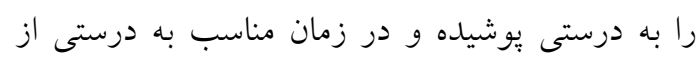

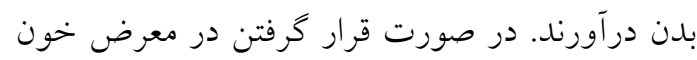
يا مايعات بدن بيماران، كاركنان بخش بهراشت بايد

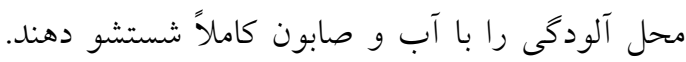
بيمارانى كه نتيجه تست آنها مثبت شده بايد ايزوله

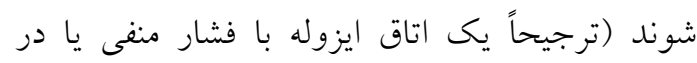
غير اين صورت يك اتاق جدا با تهويه مناسب). همجِنين
داروى رمدسيوير (Remdesivir)، آنالوگ نو كلئوتيدى

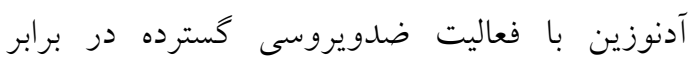

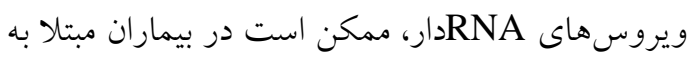

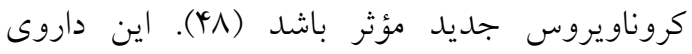

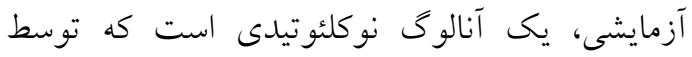
شركت داروسازى Gilead Sciences ساخنه شده است. اين دارو كه توسط اداره غذا و دارو (FDA) هنوز

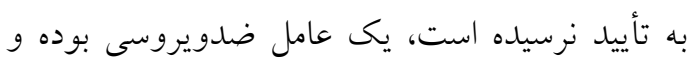
عليه ويروس هاى ابولا و SARS ساخته شده بود و هم اكنون اثربخشى اين دارو بر روى كروناويروس جديد SARS-CoV-2

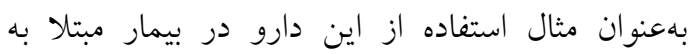
كروناويروس COVID-19 ساكن امريكا منجر به كاهش بار ويروسى (Viral load) در نمونههاى نازوفارنزيال و اوروفانزيال شده و وضعيت بالينى اين بيمار بهبود يافته

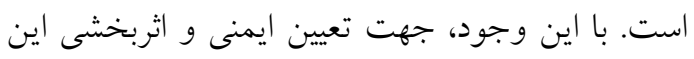

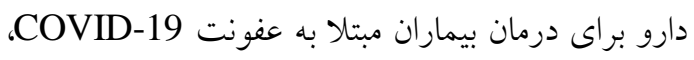

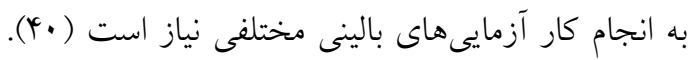
از پِلاسما درمانى مىتوان بهعنوان استراتزى درمانى ديخر نام برد. در اين روش، يلاسماى افرادى كه از بيمارى COVID-19 ايمنسازى غيرفعال استفاده مى گردد.

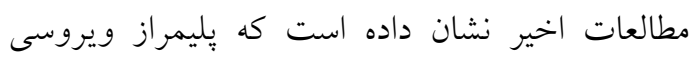
ممكن است الخوى مناسبى براى طراحى داروهاى ضدويروسى جديد براى جلوكيرى از ت تكثير كروناويروس SARS باشد (\$9) و به دليل شباهت

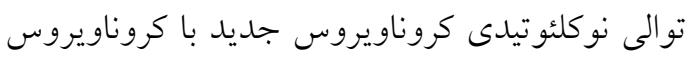
اين اطلاعات مىتواند در ساخت داروهاى SARS جديد عليه كروناويروس جديد بسيار مؤثر باشد. كلروكين فسفات، يكى ديخر از داروهايى است كه نتايج خوبى را عليه ينومونى كروناويروس جديد در مطالعات 
بايد كاملاً با مواد فوق شستشو داده شوند. سبس ماسك نَ

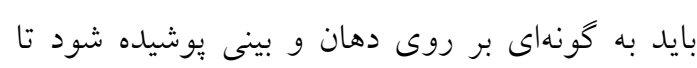

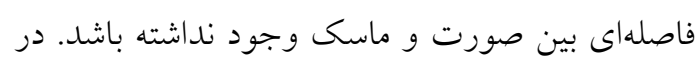
هنخام استفاده از ماسك، از دست زدن ون و لمس وآ آن بايد

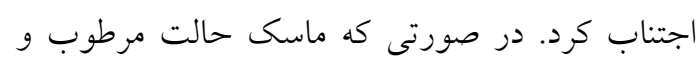
نمدار به خود گرفت، بايد اقدام به تعويض آن آن نمود.

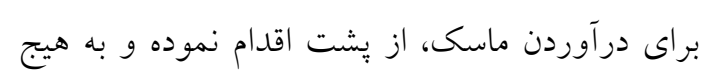
عنوان نبايد تماسى با جلوى ماسك وجود داشته باشد. سبس ماسك استفاده شده بايد بلافاصله در يكى سطل بالِ

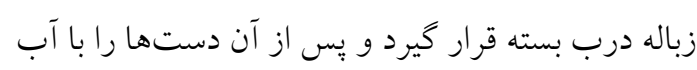

$$
\text { و صابون شستشو داد. }
$$

ه- جهت خشى كردن دستها بايد از دستمال كاغذى ئس يا دستخاه دست خشككن اتوماتيك استفاده نمود. دستخاه دست خشكىن اتوماتيك به تنهايى قادر به از

$$
\text { بين بردن ويروس ها نيست. }
$$

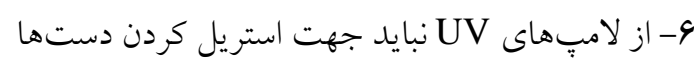
يا نواحى ديخر يوست استفاده شود. در صورت استفاده

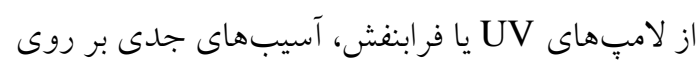

$$
\text { بوست ايجاد خواهد شد. }
$$

- V در حال حاضر دقيقاً مشخص نيست كه هـ كروناويروس COVID-19 جهه مدت بر روى سطوح

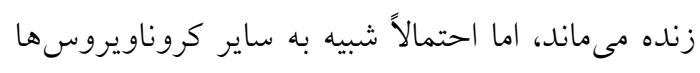

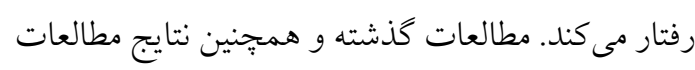
اخير نشان مىدهند كه كروناويروس

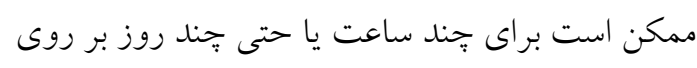

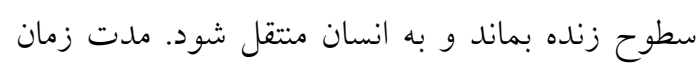

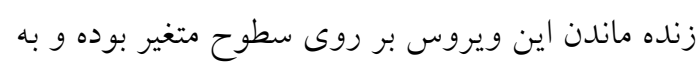
عوامل مختلفى نظير نوع سطح، دما يا رطوبت محيط

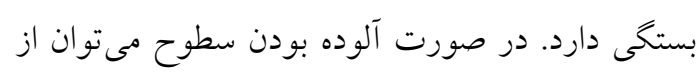

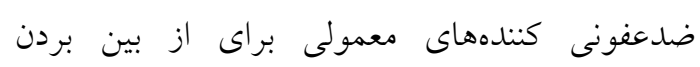

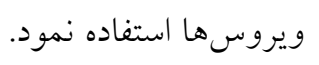

در صورتى كه علائم بعد از YY ساعت بهبود بيدا كرد و نتيجه دو تست متوالى منفى شد، شخص مى ثى تواند از

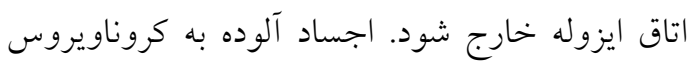
بايد سوزانده شود يا در قسمت هاى عميقتر زمين دفن

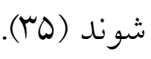
در حال حاضر هيج واكسنى جهت بيشخيرى از بيمارى

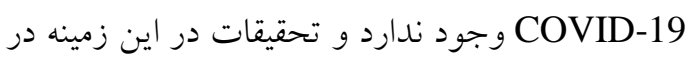
حال انجام مىباشد. بهطور كلى اقدامات زير جهت

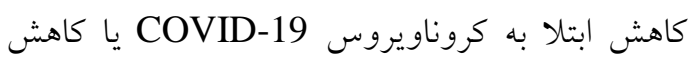

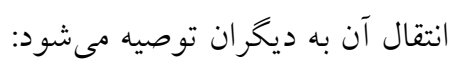
1- در هنخام عطسه و سرفه، دهان و بينى بايد با بازوها يا دستمال كاغذى يوشانده شود. در صورت استفاده از

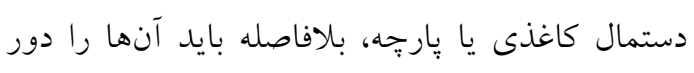
انداخته و دستان شسته شوند. r - شستشوى دستها با آب و صابون حداقل به مدت وند

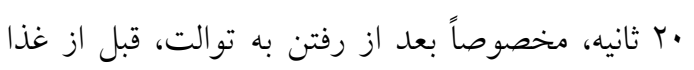

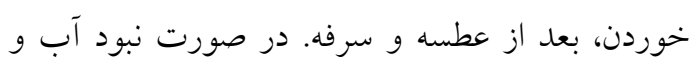

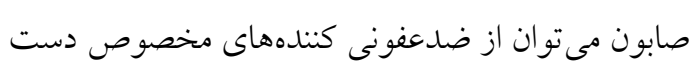
حاوى الكل (حداقل •9 درصد الكل) استفاده نمود. r- دستهاى نشسته نبايد با خشمها، بينى يا دهان تماس داشته باشد. ץ بر طبق توصيه سازمان بهداشت جهانى، افراد سالم

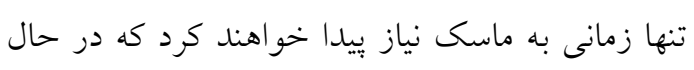
مراقبت از يك فرد بيمار يا مشكوى به بيمارى باشند. بئ.

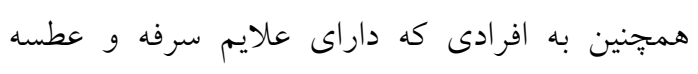
هستند توصيه مىشود تا از ماسك استفاده نمايند.

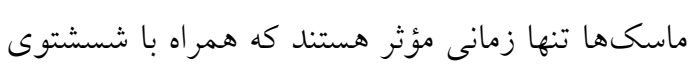

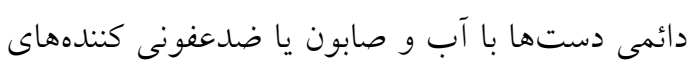
مخصوص دست حاوى الكل باشند. افراد سالمى كه

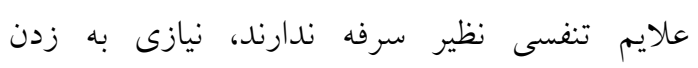
ماسكهاى يزشكى ندارند. قبل از ماسك زدن، دستها 


$$
\text { نتيجه گيرى }
$$

با توجه به خصوصيات منحصر به فرد ماده زنتيكى كروناويروس ها و همجنين مكانيسم تكثير آنها، ظهور

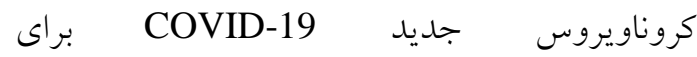
ويروسشناسان دور از انتظار نبوده است. از جمله اين ويزگ هاى خاص مىتوان به ميزان بالاى نوتركيبى زنتيكى اين ويروس اشاره نمود كه هرجيند سال يكبار منجر به يُيدار شدن سويههاى جديد و ناشناخته

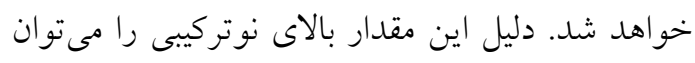

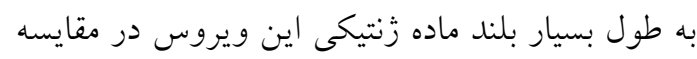

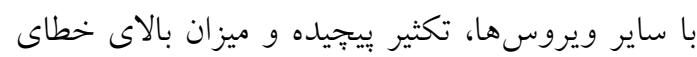

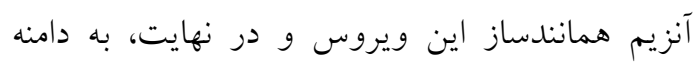

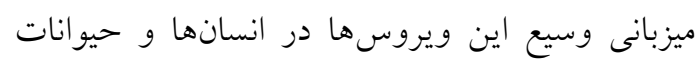

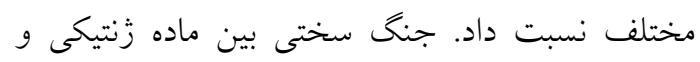
هوش ويروسى با عقل و هوش انسانى در جريان است

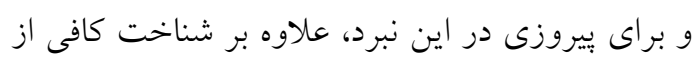

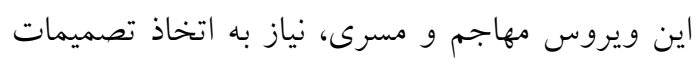
كنتلى صحيح و به موقع از سوى كشورها و اهتمام به ونه انجام اقدامات محافظتى و بهداشتى شخصى مى باشد. تضاد منافع هيجگ گونه تعارض منافع توسط نويسندكان بيان

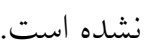

^- تا به حال شواهدى مبنى بر اين كه حيوانات خانكى نظير سگ و گربه به كروناويروس COVID-19 آلوده باشند يا بتو انند اين ويروس را منتشر كنند وجود ندارد.

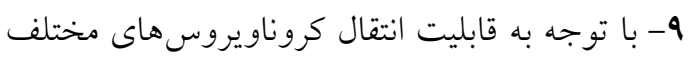

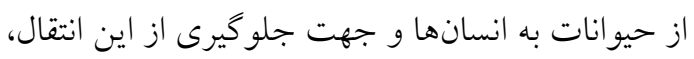

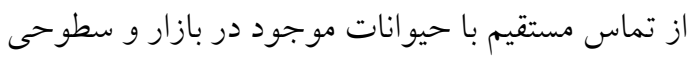
كه در تماس با اين حيوانات هستند بايد اجتناب كرد. از خوردن محصولات دامى و حيوانى خام يا نيميخته نيز بايد اجتناب كرد. • ا- جهت جلو گيرى از ابتلا، افراد سالم بايد حداقل r-1 متر از فردى كه به علايم تنفسى مبتلا هست فاصله

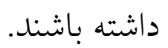
11- افزون بر اقدامات بيشخيرانه و كنترلى ذكر شده، اقدامات احتياطى بيشترى در ارتباط با كاركنان بهداثتى

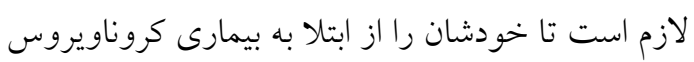

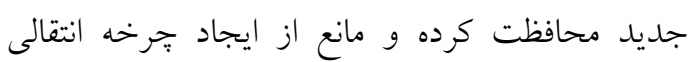

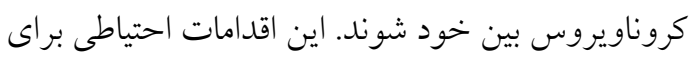
كاركنان بهداشتى كه از بيماران مبتلا به مراقبت مىنمايند شامل استفاده صحيح از تجهيزات محافظتى شخصى است كه شامل انتخاب صحيح اين تجهيزات، آموزشهاى لازم جهت استفاده صحيح آنها و روش صحيح حذف و دور انداختن آنها مىباشد.

\section{References:}

1.Khan N. New Virus Discovered By Chinese Scientists Investigating Pneumonia Outbreak. (Accessed Jan 8, 2020, at https://www.wsj.com/articles/new-virusdiscovered-by-chinese-scientists-investigatingpneumonia-outbreak-11578485668)

2.Gralinski LE, Menachery VD. Return Of The Coronavirus: 2019-Ncov. Viruses 2020; 12(2): 135 .

3.Novel 2019 Coronavirus Genome. virological.org. (Accessed January 19, 2020, at http://virological.org/t/novel-2019coronavirus-genome/319)

4.GSAID Database. 2020 Coronavirus. (Accessed January 19, 2020, at Https://Www.Gisaid.Org)

5.Novel Coronavirus-Japan (Ex-China). World Health Organization. Novel CoronavirusJapan (Ex-China). (Accessed January 19, 2020, at https://www.who.int/csr/don/16-january2020-novel-coronavirus-japan-ex-china/en/) 
6.Novel Coronavirus - China. World Health Organization. (Accessed January 12, 2020, at https://www.who.int/csr/don/12-january-2020novel-coronavirus-china/en/)

7.Lai CC, Shih TP, Ko WC, et al. Severe Acute Respiratory Syndrome Coronavirus 2 (SARS-Cov-2) And Corona Virus Disease-2019 (COVID-19): The Epidemic And The Challenges. Int J Antimicrob Agents (In press) 2020; 105924.

8.Gorbalenya EA, Baker SC, Baric RS, et al. Severe Acute Respiratory Syndrome-Related Coronavirus-The Species And Its Viruses, A Statement Of The Coronavirus Study Group. Biorxiv. In press 2020.

9.International Committee on Taxonomy of Viruses ICTV. (Accessed January 19, 2020, at https://talk.ictvonline.org/)

10.Wu A, Peng Y, Huang B, et al. Genome Composition And Divergence Of The Novel Coronavirus (2019-Ncov) Originating In China. Cell Host Microbe (In press) 2020; S1931-3128(20)30072-X.

11.Lam TTY, Shum MHH, Zhu HC, et al. Identification Of 2019-nCoV Related Coronaviruses In Malayan Pangolins In Southern China. Biorxiv. In press 2020.

12.Lu R, Zhao X, Li J, et al. Genomic Characterisation And Epidemiology Of 2019 Novel Coronavirus: Implications For Virus Origins And Receptor Binding. Lancet 2020; 395(10224): 565-74.

13.Zhang L, Shen F, Chen F, et al. Origin And Evolution Of The 2019 Novel Coronavirus. Clin Infect Dis (In press) 2020.

14.China Focus: Pangolins A Potential Intermediate Host Of Novel Coronavirus: Study. Xinhuanet. (Accessed February 7, 2020, at http://www.xinhuanet.com/english/202002/07/c_138764153.htm)

15.Zhou P, Yang XL, Wang XG, et al. Discovery Of A Novel Coronavirus Associated With The Recent Pneumonia Outbreak In Humans And Its Potential Bat Origin. Biorxiv. In press 2020. 16.Li Q, Guan X, Wu P, et al. Early Transmission Dynamics In Wuhan, China, Of Novel Coronavirus-Infected Pneumonia. New Engl J Med (In press) 2020.
17.World Health Organization. Novel Coronavirus(2019-Ncov) Situation Report-7. (Accesses January 27, 2020, at https://www.who.int/docs/default-

source/coronaviruse/situationreports/20200127-sitrep-7-2019-ncov.pdf)

18.China's National Health Commission News Conference On Coronavirus. New York Times. (Accesses January 26, 2020, at https://www.nytimes.com/2020/01/26/world/c hina-coronavirus.html)

19.Symptoms Of Novel Coronavirus (2019-Ncov). CDC. (Accessed February 29, 2020, at https://www.cdc.gov/coronavirus/2019ncov/about/symptoms.html)

20.Bai Y, Yao L, Wei T, et al. Presumed Asymptomatic Carrier Transmission Of COVID19. J Am Med Assoc. Available from: URL: https://jamanetwork.com/journals/jama/fullarticle/ 2762028

21.Coronavirus Incubation Could Be As Long As 27 Days, Chinese Provincial Government Says. Reuters. (Accesses Feb 22, 2020, at https://www.reuters.com/article/us-chinahealth-incubation/coronavirus-incubationcould-be-as-long-as-27-days-chineseprovincial government-saysidUSKCN20G06W)

22.Yang Y, Lu Q, Liu M, et al. Epidemiological And Clinical Features Of The 2019 Novel Coronavirus Outbreak In China. Medrxiv. In press 2020 .

23.Heymann DL, Shindo N. COVID-19: What Is Next For Public Health?. Lancet 2020; 395(10224): 542-45.

24.Zu ZY, Jiang MD, Xu PP, et al. Coronavirus Disease 2019 (COVID-19): A Perspective From China. Radiology (In press) 2020; 200490.

25.Huang C, Wang Y, Li X, et al. Clinical Features Of Patients Infected With 2019 Novel Coronavirus In Wuhan, China. Lancet 2020; 395(10223): 497-506.

26.Chen N, Zhou M, Dong X, et al. Epidemiological And Clinical Characteristics Of 99 Cases Of 2019 Novel Coronavirus Pneumonia In Wuhan, China: A Descriptive Study. Lancet 2020; 395(10223): 507-13. 
27.Wong C, Lam C, Wu A, et al. Plasma Inflammatory Cytokines And Chemokines In Severe Acute Respiratory Syndrome. Clin Exp Immunol 2004; 136(1): 95-103.

28.Neumann C, Scheffold A, Rutz S. Functions And Regulation Of $\mathrm{T}$ Cell-Derived Interleukin-10. Semin Immunol 2019; 44: 101344.

29.Jaillon S, Berthenet K, Garlanda C. Sexual Dimorphism In Innate Immunity. Clin Rev Allergy Immunol 2019; 56(3): 308-21.

30.Libert C, Dejager L, Pinheiro I. The $\mathrm{X}$ Chromosome In Immune Functions: When A Chromosome Makes The Difference. Nat Rev Immunol 2010; 10(8): 594-604.

31.Sun P, Qie S, Liu Z, et al. Clinical Characteristics Of 50466 Patients With 2019-Ncov Infection. Medrxiv. In press 2020.

32.Xu J, Zhao S, Teng T, et al. Systematic Comparison Of Two Animal-To-Human Transmitted Human Coronaviruses: SARS-Cov2 And SARS-Cov. Viruses 2020; 12(2): e244.

33.Al Awaidy ST, Khamis F. Middle East Respiratory Syndrome Coronavirus (MERS-Cov) In Oman: Current Situation And Going Forward. Oman Med J 2019; 34(3): 181-3.

34.Wu Z, Mcgoogan JM. Characteristics Of And Important Lessons From The Coronavirus Disease 2019 (COVID-19) Outbreak In China: Summary Of A Report Of 72314 Cases From The Chinese Center For Disease Control And Prevention. J Am Med Assoc. In press 2020.

35.Wu YC, Chen CS, Chan YJ. Overview Of The 2019 Novel Coronavirus (2019-Ncov): The Pathogen Of Severe Specific Contagious Pneumonia (SSCP). J Chin Med Assoc. In press 2020.

36.Chan JFW, Yuan S, Kok KH, et al. A Familial Cluster Of Pneumonia Associated With The 2019 Novel Coronavirus Indicating Person-ToPerson Transmission: A Study Of A Family Cluster. Lancet 2020; 395(10223): 514-23.

37.Guan WJ, Ni ZY, Hu Y, et al. Clinical Characteristics Of 2019 Novel Coronavirus Infection In China. Medrxiv. In press 2020.

38.Chen H, Guo J, Wang C, et al. Clinical Characteristics And Intrauterine Vertical Transmission Potential Of COVID-19 Infection
In Nine Pregnant Women: A Retrospective Review Of Medical Records. Lancet 2020. Available from: URL: https://www.thelancet.com/journals/lancet/arti cle/PIIS0140-6736(20)30360-3/fulltext

39.Coronavirus Disease 2019 (COVID-19). CDC. (Accessed February 28, 2020, at https://www.cdc.gov/Coronavirus/2019-

Ncov/About/Transmission.Html)

40.Holshue ML, Debolt C, Lindquist S, et al. First Case Of 2019 Novel Coronavirus In The United States. New Engl J Med 2020.

41.Liu Y, Gayle AA, Wilder-Smith A, et al. The Reproductive Number Of COVID-19 Is Higher Compared To SARS Coronavirus. J Travel Med 2020.

42.Chen J. Pathogenicity And Transmissibility Of 2019-Ncov-A Quick Overview And Comparison With Other Emerging Viruses. Microbes Infect. In press 2020.

43.World Health Organization. Coronavirus Disease 2019(COVID-19): Situation Report-30. (Accesses February 19, 2020, at Https://Www.Who.Int/Docs/Default-

Source/Coronaviruse/Situation-

Reports/20200219-Sitrep-30-Covid-

19.Pdf?Sfvrsn=6e50645_2)

44.Alshahrani MS, Sindi A, Alshamsi F, et al. Extracorporeal Membrane Oxygenation For Severe Middle East Respiratory Syndrome Coronavirus. Ann Intensive Care 2018; 8(1): 3. 45.Chu CM, Cheng VC, Hung IF, et al. Role Of Lopinavir/Ritonavir In The Treatment Of SARS: Initial Virological And Clinical Findings. Thorax 2004; 59(3): 252-6.

46.Arabi YM, Alothman A, Balkhy HH, et al. Treatment Of Middle East Respiratory Syndrome With A Combination Of LopinavirRitonavir And Interferon-B1b (MIRACLE Trial): Study Protocol For A Randomized Controlled Trial. Trials 2018; 19(1): 81.

47.Lim J, Jeon S, Shin HY, et al. Case Of The Index Patient Who Caused Tertiary Transmission Of Coronavirus Disease 2019 In Korea: The Application Of Lopinavir/Ritonavir For The Treatment Of COVID-19 Pneumonia Monitored By Quantitative RT-PCR. J Korean Med Sci 2020; 35(6): e79. 
48.Mulangu S, Dodd LE, Davey Jr RT, et al. A Randomized, Controlled Trial Of Ebola Virus Disease Therapeutics. New Engl J Med 2019; 381(24): 2293-303.

49.Kirchdoerfer RN, Ward AB. Structure Of The SARS-Cov Nsp12 Polymerase Bound To Nsp7
And Nsp8 Co-Factors. Nat Commun 2019; 10(1): 1-9.

50.Gao J, Tian Z, Yang X. Breakthrough: Chloroquine Phosphate Has Shown Apparent Efficacy In Treatment Of COVID-19 Associated Pneumonia In Clinical Studies. Biosci Trends. In press 2020. 


\title{
Novel Coronavirus Disease 2019 (COVID-19): An Emerging Infectious Disease in the 21st Century
}

\author{
A. Tavakoli $(P h D)^{1 *}$, K. Vahdat $(M D)^{2}$, M. Keshavarz $(P h D)^{2 * *}$ \\ ${ }^{1}$ Department of Medical Virology, School of Medicine, Iran University of Medical Sciences, Tehran, Iran \\ ${ }^{2}$ The Persian Gulf Tropical Medicine Research Center, The Persian Gulf Biomedical Sciences Research Institute, \\ Bushehr University of Medical Sciences, Bushehr, Iran
}

(Received 25 Feb, $2020 \quad$ Accepted 29 Feb, 2020)

\begin{abstract}
Background: At the beginning of the New Year 2020, China alerted the world health organization (WHO) to a cluster of unusual pneumonia cases in Wuhan. After extensive speculation, eventually a new species of coronavirus introduced as the causative pathogen of the disease. Coronavirus disease 2019 (COVID-19) is a name for the disease, and the virus that causes it is known $S A R S-C o V-2$. The very rapid spread of the COVID-19 in China and in many other countries has caused fear among people across the world. The novel coronavirus outbreak declared a Public Health Emergency of International Concern on 30 January 2020.

Materials and Methods: Several databases such as PubMed, Scopus, Google scholar, and BioRxiv were searched for publications reporting on the novel coronavirus up to 29 February 2020. Literature searches were performed using keywords including "Coronavirus 2019", "2019-nCoV", "COVID-19", and "SARS-CoV-2". Moreover, websites such as the World Health Organization (WHO) and the Centers for Disease Control and Prevention (CDC) were searched to retrieve updated data and statistics regarding the novel coronavirus. We extracted data on the epidemiology, pathogenesis, virology, clinical manifestations, transmission routes, diagnosis, treatment, and prevention measures.

Results: From the 1416 articles identified in the initial search, 53 were remained after title and abstract screening. After full-text review, 37 articles were eligible to include in our study. Incubation period for COVID-19 is between 2-10 days, according to the World Health Organization (WHO). The case fatality rate in patients infected with $S A R C-C o V-2$ is $4.3 \%$, and the results indicate that the mortality is higher in elderly individuals and patients with chronic conditions including patients with coronary artery disease, diabetes, chronic pulmonary disease, and hypertension. The mortality rate in healthy subjects is less than $1 \%$.

Conclusion: The outbreak caused by the novel coronavirus is larger than the previous human coronaviruses, showing that the SARS-CoV-2 is an extremely contagious virus. However, the mortality rate of COVID-19 is lower than that of other coronaviruses diseases such as SARS or MERS and other viruses like HIV and Ebola. Currently, due to the lack of an effective treatment and vaccine, the best way to deal with the COVID-19 disease is to prevent transmission and spread of the virus and to execute personal protective measures.
\end{abstract}

Keywords: Coronavirus 2019, COVID-19, SARS-CoV-2, Coronavirus pneumonia, Novel coronavirus

OIran South Med J.All right sreserved

Cite this article as: Tavakoli A, Vahdat K, Keshavarz M. Novel Coronavirus Disease 2019 (COVID-19): An Emerging Infectious Disease in the 21st Century. Iran South Med J 2020; 22(6): 432-450

Copyright $\odot 2020$ Tavakoli, et al. This is an open-access article distributed under the terms of the Creative Commons Attribution-noncommercial 4.0 International License which permits copy and redistribute the material just in noncommercial usages, provided the original work is properly cited.

***Address for correspondence: The Persian Gulf Tropical Medicine Research Center, The Persian Gulf Biomedical Sciences Research Institute, Bushehr University of Medical Sciences, Bushehr, Iran. Email: Keshavarz.m@bpums.ac.ir

*ORCID: 0000-0003-1857-0610

**ORCID: 0000-0002-3647-1619

Website: http://bpums.ac.ir

Journal Address: http://ismj.bpums.ac.ir 